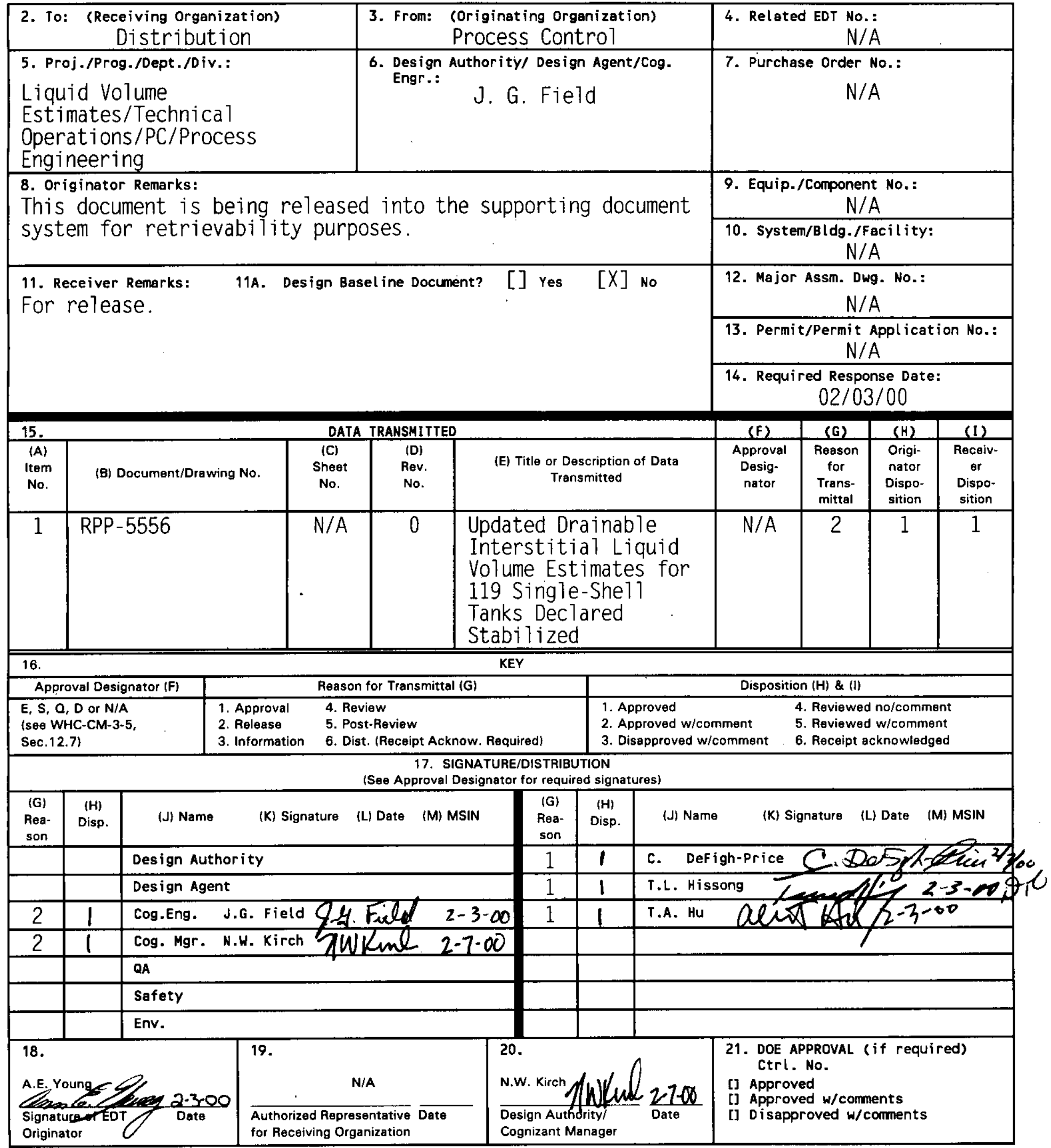




\section{Updated Drainable Interstitial Liquid Volume Estimates for 119 Single-Shell Tanks Declared Stabilized}

Jim G. Field

CH2M HILL Hanford Group, Inc. . Richland. WA 99352

U.S. Department of Energy Contract DE-AC06-96RL13200

$\begin{array}{lll}\text { EDT/ECN: } & \text { EDT }-628376 & \text { UC: } 2070 \\ \text { Org Code: } & 74 \text { B50 } & \text { CACN/COA: 103352/BA40 } \\ \text { B\&R Code: } & \text { EW } 3120074 & \text { Total Pages: } 45\end{array}$

Key Words: Drainable Interstitial Liquid Volume Estimates, Drainable, Interstitial Liquid, Volume Estimates, Volume, Single-Shell Tanks. SSTS. Stabilized

Abstract: $\quad N / A$

TRADEMARK DISCLAIMER. Reference herein to any specific commercial product, process, or service by trade nane, trademark, manufacturer, or otherwise, does not necessarily constitute or imply its endorsement, recommendation, or favoring by the United States Government or any agency thereof or its contractors or subcontractors.

Printed in the United States of America. To obtain copies of this document, contact: Document Control Services, P.O. Box 950, Mailstop H6-08, Richland WA 99352, Phone (509) 372-2420; Fax (509) 376-4989.
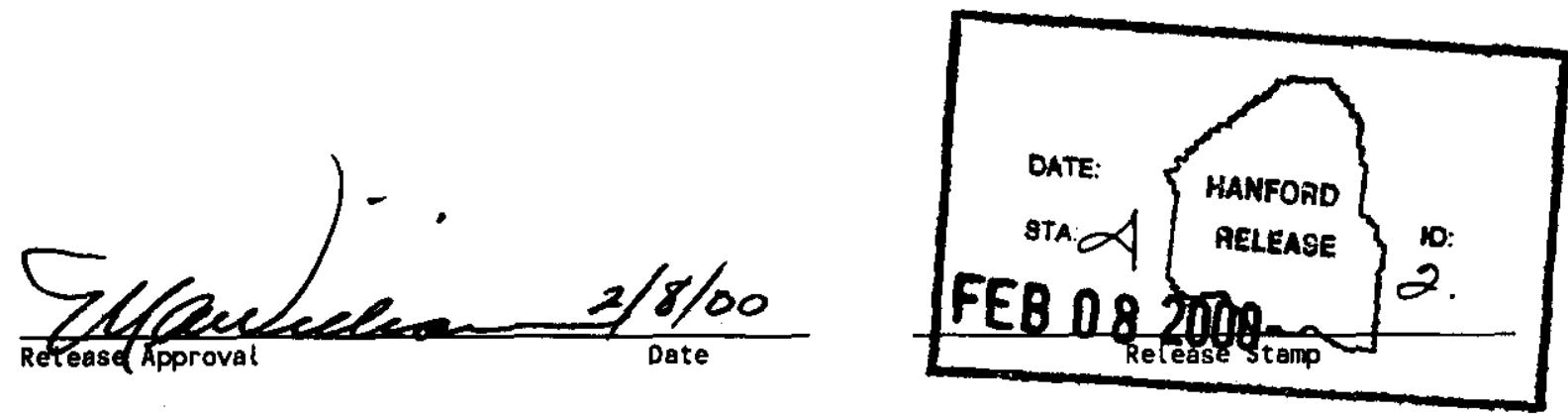

Approved for Public Release 
RPP-5556

Revision 0

\section{Updated Drainable Interstitial Liquid Volume Estimates for 119 Single-Shell Tanks Declared Stabilized}

\section{J. G. Field}

CH2M HILL Hanford Group, Inc.

\section{Date Published}

February 2000

Prepared for the U.S. Department of Energy Office of River Protection

CH2M HILL Hanford Group, Inc.

Richland, Washington 


\section{CONTENTS}

1.0 INTRODUCTION

1.1 SUMMARY

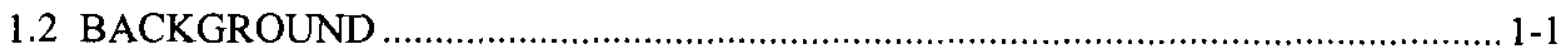

1.3 SCOPE

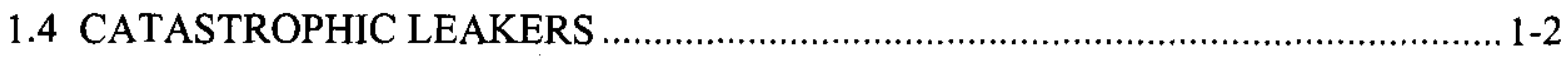

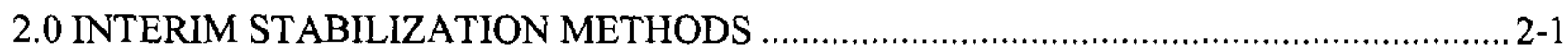

2.1 JET PUMPING

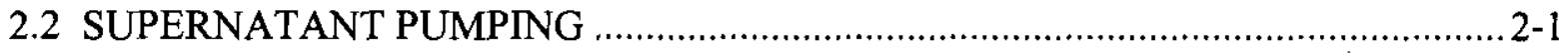

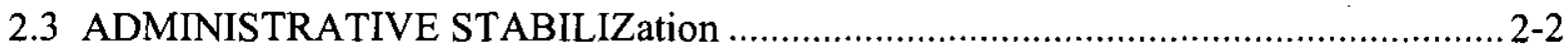

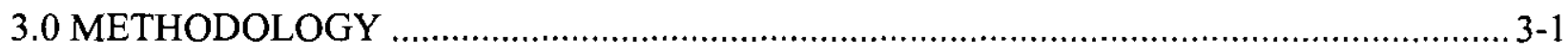

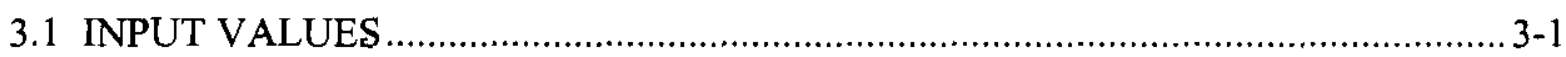

3.1.1 Waste Volume Estimates............................................................................ 3-1

3.1.2 Measured Liquid Levels ............................................................................... 3-1

3.1.3 Drainable Porosity Estimates .......................................................................... 3-1

3.1.4 Capillary Height ....................................................................................... 3-4

3.1.5 Unpumpable Region.................................................................................. 3-4

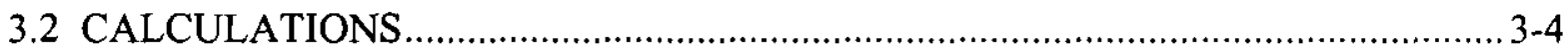

3.2.1 Establishing a Common Reference Point ……............................................... 3-4

3.2.2 Using Liquid Observation Well Readings ....................................................... 3-5

3.2.3 Drainable Interstitial Liquid ...................................................................... 3-5

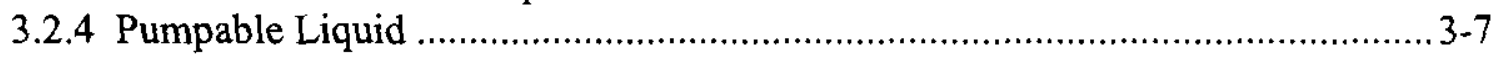

4.0 ASSUMPTIONS AND TANK-SPECIFIC NOTES................................................... $4-1$

5.0 CONCLUSION

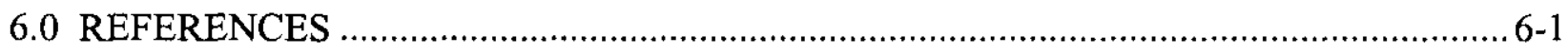

\section{APPENDICES}

APPENDIX A: POROSITY CALCULATIONS AND BASIS FOR DRAINABLE INTERSTITIAL LIQUID DIL ESTIMATES DIFFERING FROM

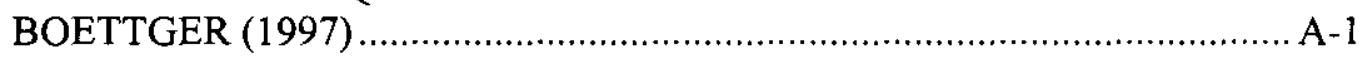

APPENDIX B: SPREADSHEET CALCULATIONS AND VERIFICATION ………............ B-1 
RPP-5556, Rev. 0

\section{LIST OF FIGURES}

Figure 3-1. Representation of Saltwell Pump with Associated Dimensions of Unpumpable and Capillary Liquid Regions .................................................................................. 3-3

\section{LIST OF TABLES}

Table 5-1. Estimated Drainable Interstitial Liquid and Pumpable Liquid Remaining Volumes for 119 Single-Shell Tanks $5-2$

\section{LIST OF TERMS}

$\begin{array}{ll}\text { DIL } & \text { drainable interstitial liquid } \\ \text { DOE } & \text { U.S. Department of Energy } \\ \text { DST } & \text { double-shell tank } \\ \mathrm{ft} & \text { feet } \\ \mathrm{gal} & \text { gallons } \\ \mathrm{gal} / \mathrm{hr} & \text { gallons per hour } \\ \mathrm{gal} / \mathrm{in} . & \text { gallons per inch } \\ \mathrm{gal} / \mathrm{min} & \text { gallons per minute } \\ \mathrm{ILL} & \text { interstitial liquid level } \\ \mathrm{in} . & \text { inches } \\ \mathrm{kgal} & \text { kilogallon } \\ \text { LOW } & \text { liquid observation well } \\ \mathrm{N} / \mathrm{A} & \text { not applicable } \\ \text { PLR } & \text { pumpable liquid remaining } \\ \mathrm{SST} & \text { single-shell tank } \\ \text { vol } & \text { volume } \\ \text { \% } & \text { percent }\end{array}$


RPP-5556, Rev. 0

\subsection{INTRODUCTION}

\subsection{SUMMARY}

This document assesses the volume of drainable interstitial liquid (DIL) and pumpable liquid remaining in 119 single-shell tanks (SSTs) that were previously stabilized. Based on the methodology and assumptions presented, the DIL exceeded the stabilization criterion of less than $50,000 \mathrm{gal}$ in two of the 119 SSTs. Tank $241-\mathrm{C}-102$ had an estimated DIL of $62,000 \mathrm{gal}$, and the estimated DIL for tank 241-BY-103 was 58,000 gal. In addition, tanks 241-BX-103, 241-T-102, and 241-T-112 appear to exceed the stabilization criterion of 5,000 gal supernatant. An assessment of the source of the supernatant in these tanks is beyond the scope of this document.

The actual DIL and pumpable liquid remaining volumes for each tank may vary significantly from estimated volumes as a result of specific tank waste characteristics that are not currently measured or defined. Further refinement to the pumpable liquid and DIL volume estimates may be needed as additional tank waste information is obtained.

\subsection{BACKGROUND}

Part of the legacy of the Hanford Site is the storage of radioactive waste in SSTs. Large volumes of radioactive waste were stored in 149 underground SSTs, constructed from 1943 to 1964; and 28 underground double-shell tanks (DSTs), constructed from 1968 to 1980 . To limit the number of new DSTs that had to be constructed to store liquid radioactive waste, the U.S. Department of Energy (DOE) authorized the concentration of waste liquids until the soluble salts were precipitated. These precipitated salts were allowed to settle in the SSTs. Free supernatants were pumped from most of the SSTs by 1980 and were concentrated and stored in DSTs. No new waste additions were made to the SSTs after 1980, but the tanks have exceeded their design life and leakage from 67 SSTs is assumed or has been confirmed (Vladimiroff et al. 1999).

To reduce the potential of further SST leakage, liquid was removed from the SSTs, and the tanks were interim stabilized. As of November 1, 1999, of the 149 SSTs at the Hanford Site, 119 SSTs have been declared interim stabilized, and 30 tanks remain to be interim stabilized. Tank 241-C-106 is expected to be declared interim stabilized as a result of sluicing. A Consent Decree between the DOE and Washington State establishes the requirements for stabilizing the remaining 29 tanks. The Consent Decree requires that all tanks be interim stabilized by September 30, 2004. The criteria to stabilize a tank are that the tank must contain less than $50,000 \mathrm{gal}$ of DIL, less than $5,000 \mathrm{gal}$ of supernatant, and the pump flow must be at $0.05 \mathrm{gal} / \mathrm{min}$ or less before pumping can be discontinued (Vladimiroff et al. 1999). If a tank was supernatant pumped or if a jet pump fails before the pump flow rate decreases to less than $0.05 \mathrm{gal} / \mathrm{min}$, the tank can be declared stabilized if less than 50,000 gal of DIL and less than 5,000 gal of supernatant remain. 


\section{$1.3 \mathrm{SCOPE}$}

To maintain consistency in the methodology used to determine a tank meets the interim stabilization criteria, and to ensure all SSTs are adequately interim stabilized, the methodology presented by Field and Vladimiroff (1999) was applied to the 119 SSTs previously stabilized and the DIL and "pumpable liquid remaining" volumes were recalculated. This document presents the basis for revised DIL and pumpable liquid remaining estimates and calculation results for the 119 tanks previously stabilized to assess whether the liquid volume in any of the tanks exceeds 50,000 gal of DIL. Additional detail regarding calculations and methodology is included in Field and Vladimiroff (1999).

\subsection{CATASTROPHIC LEAKERS}

Seven of the 119 SSTs have had known catastrophic leaks (Nelson and Ohl 1999), but do not have a liquid observation well (LOW) installed. These tanks are: 241-A-105, 241-BX-102, 241-SX-110, 241-SX-113, 241-SX-115, 241-T-106, and 241-U-104. Nelson and Ohl (1999) define a catastrophic failure as a leak of 50,000 gal or more or leak rates greater than $10 \mathrm{gal} / \mathrm{hr}$. Two other tanks, 241-SX-108 and 241-SX-109, have also been shown to have significant leakage based on increased radioactivity in tank laterals.

An assessment of tank 241-SX-109 (Thompson 1999) concluded that, "although the tank definitely leaked in the past, it is improbable that there is liquid which could leak from the tank at this time." The report further states, "assuming a realistic percentage of liquid in the tank below the level sampled, a leak at $10 \%$ of the estimated rate of leaks from typical tank leaks would have emptied any accessible drainable liquid in the 58 inches below the sampled depth before 1990.”

Applying the criteria of Thompson (1999), it was assumed that any drainable liquid previously contained in tanks designated as catastrophic leakers, and in tanks 241-SX-108 and 241-SX-109, has leaked from the tank. Therefore, the interstitial liquid level for these nine tanks was assumed to be negligible, and the DIL was assumed to be " 0 ." 


\subsection{INTERIM STABILIZATION METHODS}

In the past, SSTs were interim stabilized by one of three methods: jet pumping, supernatant pumping, or administrative stabilization. Each of these methods is discussed in the following sections.

\subsection{JET PUMPING}

Jet pumping has been used to stabilize 40 of the 119 SSTs, and is the method that has been selected to stabilize the remaining 29 SSTs.

A central screened well is installed in the center of the tank, and a specially designed jet pump is installed in the well. The pump removes liquid from the central well at the fastest rate possible, which is the same rate that it drains to the well. After enough liquid is removed, the excess potential is reduced to the point where inflow into the well is reduced to less than $0.05 \mathrm{gal} / \mathrm{min}$. The pump rate decreases to $0.05 \mathrm{gal} / \mathrm{min}$ after the majority of the drainable liquid has been removed. At this point, saltwell pumping is declared complete, and an assessment is conducted to verify the DIL is less than 50,000 gal. After the tank is declared interim stabilized, it is isolated by intrusion prevention to ensure that in-tank-leakage does not occur until the tank is prepared for retrieval.

At the completion of jet pumping, the solids remaining in the tank still contain interstitial liquid on the surface of the particles and in the capillary region (this liquid is defined as non-drainable interstitial liquid). Drainable liquids will generally remain in the unpumpable region (bottom 18 inches of a tank).

\subsection{SUPERNATANT PUMPING}

As the name implies, this method was used to remove only the free-liquid or supernatant layer from the tank. Twenty-four of the SSTs were stabilized by supernatant pumping. The supernatant pump generally operates at a higher flow rate than a jet pump and is not capable of the slow pump rates achievable with a jet pump. Tanks were declared stabilized after supernatant pumping as long as the calculated DIL was below 50,000 gal.

If a tank did not contain a LOW, it was assumed that the solids remaining in the tank remain saturated after pumping. If a tank had a LOW, it was assumed that any interstitial liquids contained in solids above the interstitial liquid level (ILL) are non-drainable. Solids below the ILL were assumed to be saturated. Liquids held in the capillary region were assumed to be non-drainable. 
RPP-5556, Rev. 0

\subsection{ADMINISTRATIVE STABILIZATION}

In the past, 55 of the SSTs were determined to contain less than $50 \mathrm{kgal}$ of DIL and less than $5 \mathrm{kgal}$ of supernatant prior to pumping. These tanks were declared stabilized without pumping or "administratively stabilized." Administrative stabilization has been discontinued.

An in-tank video was taken to assess the tank contents. If a tank did not contain a LOW or if core sample data were not available, it was assumed that the solids in the tank were saturated. If a tank had an observation well, it was assumed that any interstitial liquids contained in solids above the ILL were non-drainable. Solids below the ILL were assumed to be saturated. Core sample data was also used as a basis for estimating the fraction of drainable liquid in a tank. Liquids contained within the capillary region were assumed to be non-drainable. 
RPP-5556, Rev. 0

\subsection{METHODOLOGY}

The following sections discuss inputs and calculations performed to estimate pumping volumes and DIL volumes.

\subsection{INPUT VALUES}

The primary inputs needed to estimate DIL and pumpable liquid volumes include: tank waste volume estimates, measured liquid levels, drainable porosity estimates for each waste type, capillary height, and unpumpable region. Figure 3-1 is a schematic of the saltwell pump and pumping regions. Input values for each of the tanks are shown in Table 5-1.

\subsubsection{Waste Volume Estimates}

The best-basis volumes for supernatant, saltcake, and sludge were used as input values to determine the amount of pumpable liquid in each tank. Current best-basis volumes for SSTs are presented in monthly updates of the Waste Tank Summary Report (Hanlon 1999)

\subsubsection{Measured Liquid Levels}

Interstitial liquid level measurements were obtained for 43 of the 119 tanks as a measure of the saturated liquid level. The liquid level and waste surface level were assumed to be the same, and the solids were assumed to be saturated if there was no LOW or diptube measurement. Liquid observation wells are placed in many of the tanks and record the distance to a saturated surface in the tank. Diptubes are used with jet pumping to measure the depth of liquid in the saltwell. Drainable porosity measurements and liquid level estimates based on diptubes are made after the liquid level in the diptubes equilibrates. This may take as little as a few weeks for a coarse waste with high permeability or months for waste with fine particles and low permeability.

If the waste is not entirely saturated, the LOW or diptube measurements indicate how much of the solids are saturated.

\subsubsection{Drainable Porosity Estimates}

Drainable porosity was calculated for many of the jet pumped tanks (Boettger 1997) by dividing the volume of liquid pumped over a given time period by the liquid level drawdown volume (change in liquid level height times the tank height to volume conversion factor gal/in.). 
When drainable porosity measurements were not available, drainable porosity estimates used as inputs for DIL calculations were $25 \%$ for saltcake and $15 \%$ for sludge. These values are based on average drainable porosity estimates for 33 tanks previously jet pumped (Field and Vladimiroff 1999). No statistically significant difference could be determined in the drainable porosity values for different types of saltcake or in drainable porosity values for different types of sludge. The drainable porosity value and capillary height for saltcake or sludge actually varies more as a function of particle size than of waste type (some waste designated as saltcake may have very fine particles and behave more like a sludge [i.e., low drainable porosity and long capillary height]). However, currently, little particle size information is available for any of the tank waste.

Except as shown in Appendix A, drainable porosity values for jet pumped tanks are from Boettger (1997). 
Figure 3-1. Representation of Saltwell Pump with Associated Dimensions of Unpumpable and Capillary Liquid Regions
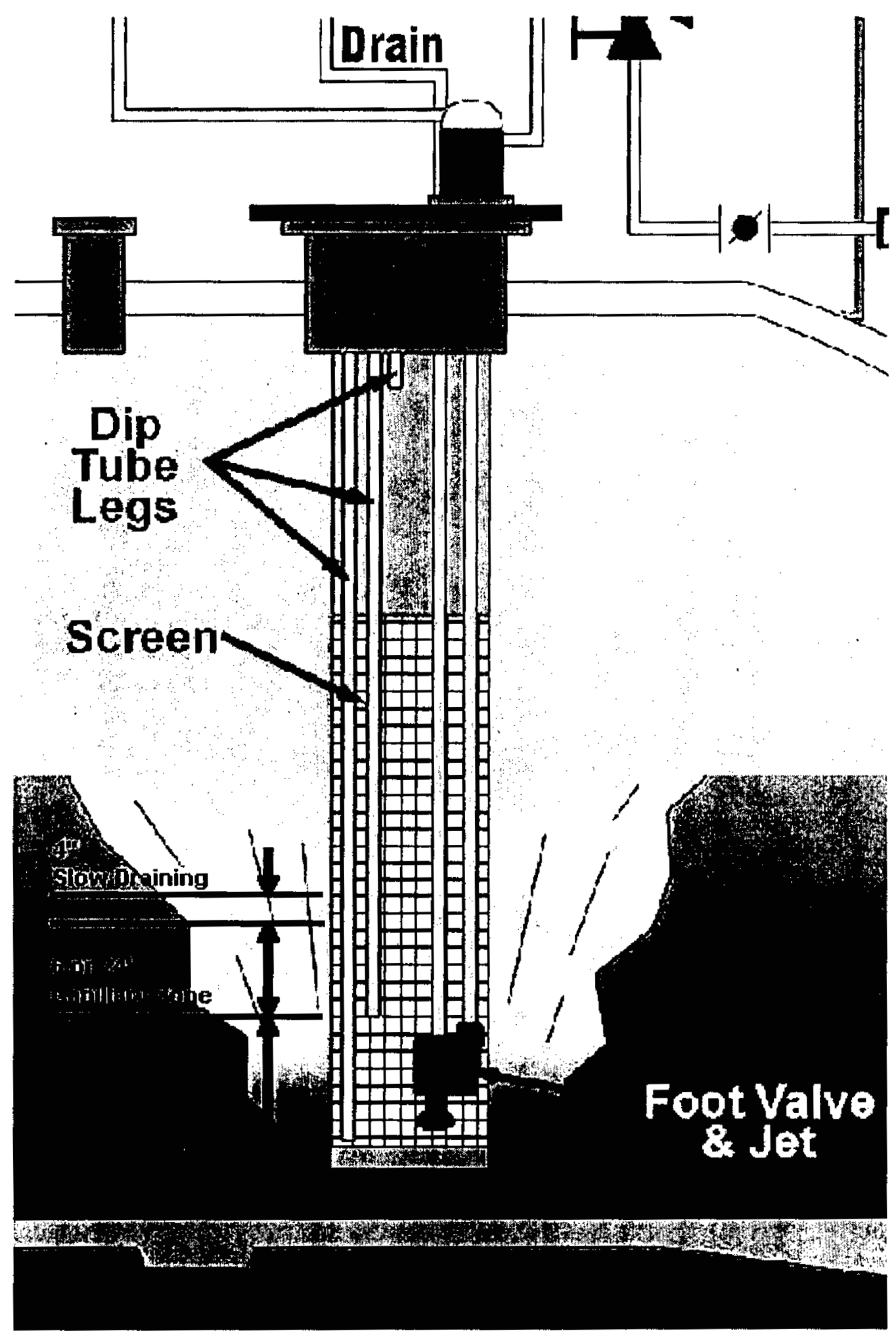


\subsubsection{Capillary Height}

Porous media typically exhibit a capillary height above a saturated layer which will sustain a liquid column. The capillary height is defined as the height where internal hydrostatic forces equal external hydrostatic forces within the waste material (Kirk 1980). Because of these forces, liquid in the capillary region will not drain from the waste. The capillary height for saltcake has been shown to range from 6 in. to over 24 in. As noted in the previous section, capillary height is largely a function of particle size, and some saltcakes may have very fine particles and a capillary height characteristic of sludge. Except as noted in Table 5-1, a capillary height of 6 in. was assumed for saltcake for these calculations (Field and Vladimiroff 1999). This assumption will tend to overestimate the amount of DIL in the saltcake.

Sludge is typically a finer, less permeable material than saltcake and generally holds more liquid. However, sludge is more hydroscopic, and the drainable porosity is lower than for saltcake. Although some sludge tanks may not drain and capillary heights may be as high as $20 \mathrm{ft}$, except as noted in Table 5-1, a sludge capillary height of $24 \mathrm{in}$. was assumed for DIL calculations (Field and Vladimiroff 1999). This assumption will tend to overestimate the amount of DIL in the sludge.

\subsubsection{Unpumpable Region}

The bottom $18 \mathrm{in.} \mathrm{of} \mathrm{a} \mathrm{tank} \mathrm{is} \mathrm{unpumpable} \mathrm{because} \mathrm{of} \mathrm{the} \mathrm{operation} \mathrm{and} \mathrm{design} \mathrm{of} \mathrm{the}$ saltwell screen (see Figure 3-1). The target minimum depth of the screen in relation to the tank bottom is approximately 2 in. above the lowest point of the tank bottom. The set point offset is 12 in., and there is an estimated 4-in. height above the capillary region that cannot support a minimum pumping rate of $0.05 \mathrm{gal} / \mathrm{min}$.

Sections 3.2.4 and 3.2.5 discuss how capillary height and the unpumpable liquid height is used to determine the amount of DIL and pumpable liquid in a tank.

\subsection{CALCUlations}

This section describes the calculations which were performed to estimate pumpable liquid remaining and DIL volumes. Calculations for each tank are presented in Appendix B.

\subsubsection{Establishing a Common Reference Point}

One hundred nine of the SSTs have dished bottoms. Only the tanks in A-Farm and AX-Farm have flat bottoms. For tanks with dished bottoms, the volume and type of waste in the dished bottom was calculated separately. The volume of waste above the dish was calculated by multiplying the height of the layer by a conversion factor of $2,754 \mathrm{gal} / \mathrm{in}$. for 100 series tanks and $196 \mathrm{gal} / \mathrm{in}$. for 200 series tanks (i.e., B-200s, T-200s, etc.). 


$$
\text { RPP-5556, Rev. } 0
$$

\subsubsection{Using Liquid Observation Well Readings}

As explained in Section 3.1.2, liquid level measurements were used to adjust the height of the solids layer for 43 of the 119 tanks. If the LOW/diptube reading indicated the ILL was in the sludge layer, the height of drainable sludge was revised. If the ILL was in the saltcake layer, the drainable sludge height was unaffected, and the saltcake height was reduced to account for only the saturated saltcake region.

There is one important difference between the LOW and diptude measurements. The diptude measures the liquid level in the saltwell and does not include the capillary region in the waste (i.e., the capillary height was not subtracted from sludge or saltcake if the ILL was determined from diptube measurements). In contrast, the LOW measures the saturated liquid level in the waste. Therefore, the LOW reading contains an unquantified portion of the capillary region.

The capillary region for highly permeable waste such as a typical saltcake is probably small compared to the total waste volume, and part of the capillary region may be only partially saturated (data is not available to quantify the saturated and unsaturated portions). Therefore, these calculations assume that the LOW measurement does not include the assumed 6-in. capillary region for waste designated as saltcake (i.e., capillary height is not subtracted from the LOW for saltcake). This assumption for saltcake may result in high calculations for DIL and pumpable liquid remaining (PLR) in saltcake.

The sludge capillary height is generally much greater than the capillary height for saltcake and often represents a greater portion of the waste matrix. Also, because sludge is less permeable with smaller pores, most of the sludge capillary region is likely "saturated." Therefore, it was assumed that the LOW measurement includes all of the capillary region for sludge (i.e. capillary height is subtracted from the LOW for sludge).

Table 5-1 shows which tanks have an ILL measurement and whether the measurement is from diptude or LOW readings.

\subsubsection{Drainable Interstitial Liquid}

The drainable interstitial liquid volume is the sum of DIL in each waste layer, less the capillary height (see Section 2.1.4). This volume includes drainable liquid in the unpumpable region. It does not include supernatant or interstitial liquid in the capillary region. The following equation was used to calculate the DIL values, rounded to the nearest 1,000 gal shown in Table 5-1:

DIL $=($ Sludge vol. below ILL - Capillary vol. sludge $)($ Sludge Drainable Porosity $)+$ (Saltcake vol. below ILL - Capillary vol. saltcake)(Saltcake Drainable Porosity)

- Capillary volume is assumed to be in only the sludge if the sludge depth is greater than 18 in. (unpumpable region) + sludge capillary height from the bottom of the tank.

- The capillary height is proportioned between the sludge and saltcake if the total sludge height is less than the unpumpable region plus the capillary height. 


\section{RPP-5556, Rev. 0}

\section{Example Calculations:}

1. Tank 241-B-107 (Saltcake and Sludge in a dish bottom tank, no LOW)

Sludge: Volume $=93,000$ gal, Capillary height $=24$ in., Drainable Porosity $=25 \%$

Saltcake: Volume $=71,000$ gal, Capillary height $=6$ in., Drainable Porosity $=15 \%$ Assume all waste is saturated.

Unpumpable volume $=18$ in., this includes the dish volume $(12,500 \mathrm{gal})$ and $6 \mathrm{in}$. above the dish which is equivalent to $16,524 \mathrm{gal}(6 \mathrm{in} . * 2,754 \mathrm{gal} / \mathrm{in}$.) Unpumpable volume $=29,024 \mathrm{gal}$

Sludge accounts for most, but not all of the capillary volume, because the tank has less than 24 in. $(66,096 \mathrm{gal})$ of sludge above the 18 -in. unpumpable region.

Volume of sludge above the unpumpable region $=$ 93,000 gal (sludge volume) $-29,024$ (unpumpable volume) $=63,976$ gal.

Relative portion of sludge capillary height $=63,976 \mathrm{gal} / 66,096 \mathrm{gal}=0.968$

The capillary height of saltcake $=$ the assumed capillary height for saltcake $(6$ in.) times the relative portion of saltcake capillary height $(1-0.968)$.

Capillary height of saltcake $=6$ in. $(1-0.968)=0.19$ in.

The DIL includes drainable liquid in the unpumpable region and the drainable liquid above the capillary height. All sludge above the unpumpable region is in the sludge capillary region and is not DIL. All of the saltcake except the capillary height 0.19 in. (523 gal) is included in the DIL.

$$
\begin{aligned}
\text { DIL } & =(29,024 \mathrm{gal})(0.15)+(71,000 \mathrm{gal} .-0.19 \text { in. } * 2,754 \mathrm{gal} / \mathrm{in} .)(0.25) \\
& =4,354 \mathrm{gal}+17,619 \mathrm{gal} \\
& =\underline{21,973} \mathrm{gal}
\end{aligned}
$$

2. Tank 241-TX-110 (Saltcake and Sludge in a dish bottom tank with diptube readings)

$$
\begin{aligned}
& \text { Sludge: Volume }=37,000 \text { gal, Drainable Porosity }=15 \% \\
& \text { Saltcake Volume }=425,000 \text { gal, Drainable Porosity }=26 \% \\
& \text { ILL }=33.0 \text { in. (from diptube, ignore capillary height) }
\end{aligned}
$$

Drainable porosity above the unpumpable region was based on jet pump drawdown measurements (Boettger 1997). Because sludge liquids were not pumped, an average drainable porosity for sludge was assumed. 


\section{RPP-5556, Rev. 0}

Because the ILL is based on diptude readings, the capillary height is assumed to be above the ILL and is not subtracted.

Converting the ILL height to an equivalent volume:

$$
\begin{aligned}
\text { ILL volume } & =\text { dish volume (bottom } 12 \mathrm{in} .)+ \text { volume above dish } \\
& =12,500 \mathrm{gal}+(33-12) \text { in. }(2,754 \mathrm{gal} / \mathrm{in} .)=70,334 \mathrm{gal}
\end{aligned}
$$

The sludge volume above the unpumpable height $=37,000-29,024=7,976 \mathrm{gal}$.

The saltcake volume below the ILL $=70,334-37,000=33,334$ gal.

DIL = unpumpable volume *sludge drainable porosity + saltcake volume below ILL* saltcake drainable porosity

$$
=29,024 \mathrm{gal} * 0.15+33,334 * 0.26=\underline{13,020 \mathrm{gal}}
$$

Calculations for all tanks and calculation verifications are included in Appendix. B

\subsubsection{Pumpable Liquid}

The pumpable liquid volume is the sum of DIL plus the supernatant minus the unpumpable liquid volume. The unpumpable liquid height is the bottom 18-in. for all tanks based on operational limitations (see Section 3.1.5). The following equation was used to calculate the DIL values shown in Table 5-1:

PLR = DIL - (unpumpable region) $($ drainable porosity) + supernatant

\section{Example Calculations:}

1. Tank 241-B-107

$$
\begin{aligned}
& \text { unpumpable volume }=12,500 \mathrm{gal}+6 \mathrm{in} .(2,754 \mathrm{gal} / \mathrm{in} .)=29,024 \mathrm{gal} \\
& \begin{aligned}
\text { PLR } & =21,973 \mathrm{gal}-29,024 \mathrm{gal}(0.15)+1,000 \mathrm{gal} \\
& =\underline{18,619} \mathrm{gal}
\end{aligned}
\end{aligned}
$$

2. Tank 241-TX-110

$$
\text { unpumpable volume }=12,500 \mathrm{gal}+6 \mathrm{in} .(2,754 \mathrm{gal} / \mathrm{in} .)=29,024 \mathrm{gal}
$$

$$
\begin{aligned}
\text { PLR } & =13,020 \mathrm{gal}-(29,024 \mathrm{gal}) 0.15+0 \\
& =\underline{8.666} \mathrm{gal}
\end{aligned}
$$


RPP-5556, Rev. 0

This page intentionally left blank. 
RPP-5556, Rev. 0

\subsection{ASSUMPTIONS AND TANK-SPECIFIC NOTES}

The following assumptions were used to calculate DIL and pumpable liquid volumes:

- $\quad$ Best-basis tank volume and waste type estimates were used (Hanlon 1999).

- The saltwell pumping system is located in the center of the tank, and all calculations are referenced to the tank bottom center line.

- The ILL readings (LOW or diptube) were referenced to the tank bottom centerline. The following assumptions were made regarding the capillary region with respect to the ILL (see Section 3.2.2):

If the ILL was from LOW readings:

- The sludge capillary height was assumed to be below the ILL and the capillary region was subtracted from the measured liquid level to calculate DIL and PLR.

- The saltcake capillary height was assumed to be above the ILL and was not subtracted from the measured liquid level to calculate DIL and PLR.

If the ILL was from diptude readings:

- The saltcake and sludge capillary heights were assumed to be above the ILL and were not subtracted from the measured liquid level to calculate DIL and PLR.

- The DIL was assumed to be " 0 " for the seven tanks with known catastrophic leaks (Nelson and Ohl 1999) and for tanks 241-SX-108 and 241-SX-109 (Thompson 1999).

- The waste is layered from top to bottom in the following order: supernatant, saltcake, and sludge. All layers are flat and cover the entire diameter of the tank.

- $\quad$ Average porosities for sludge and saltcake are assumed except where drainable porosity measurements are available for jet pumped tanks.

- Except for tanks with LOW readings or diptube measurements, it is assumed the solids in the tank are saturated with drainable liquid.

- There is only one capillary region in the tank. A 6-in. capillary region is used for saltcake, and a 24 -in. region is used for sludge. If less than 18 in. of sludge is in a tank, the capillary height is prorated proportionally between the sludge and saltcake capillary heights. 


\section{RPP-5556, Rev. 0}

- The 18-in. unpumpable region is comprised of the following dimensions: 2 in. below the saltwell, 12 in. from the bottom of the saltwell to the process control set point, and 4 in. of slow draining region (Figure 3-1). 


\subsection{CONCLUSION}

Table 5-1 lists the supernatant, saltcake, and sludge volume estimates used to estimate DIL and pumpable liquid volumes remaining for each tank. If a LOW reading was available to measure the liquid level in the solids, this was also included in the table. As noted in Section 1.0, the revised DIL and pumpable liquid estimates are based on the methodology presented in Field and Vladimiroff (1999) and updated best-basis tank waste volume estimates.

Two of the tanks exceeded the 50,000 gal DIL criteria for stabilization: $241-\mathrm{C}-102$ and 241-BY-103. Liquid volume estimates for these tanks should be further assessed. Both tanks have an ILL measurement.

The ILL for tank 241-C-102 was based on diptube measurements, and jet pumping was stopped before reaching a $0.05 \mathrm{gal} / \mathrm{min}$ pump rate due to pump failure.

Tank 241-BY-103 was also jet pumped, and pumping was stopped due to pump failure. This tank was declared stabilized previously based on an estimated porosity of $13 \%$ and a DIL of $38.3 \mathrm{kgal}$ (Saueressig 1997). Since then, the LOW reading has gradually increased from 99.1 in. to 116.1 in., and liquid intrusion is suspected (Hanlon 1999). Based on the 99.1 in. LOW measurements, and the assumptions presented in this document, the drainable porosity was re-calculated to be about $20 \%$ with a current DIL of $58 \mathrm{kgal}$. Because the waste is classified as a saltcake, it was assumed that the 6-in. capillary height is above the saltcake (see Section 3.2.2). The slow backflow into the saltwell and neutron probe scans indicate that although the waste is classified as saltcake, it is highly impermeable and behaves more like sludge. In this case, the capillary height would be 24 in. rather than 6 in. and would be subtracted from the ILL. The DIL falls below $50,000 \mathrm{gal}$ if capillary height is subtracted from the ILL.

With the data currently available, there is still a large amount of uncertainty in estimating the DIL and pumpable liquid volume remaining in a tank. Actual liquid volume estimates will vary depending on the actual permeability of saltcake and sludge, and supernatant volumes. 
RPP-5556, Rev. 0

Table 5-1. Estimated Drainable Interstitial Liquid and Pumpable Liquid Remaining Volumes for 119 Single-Shell Tanks (3 pages)

\begin{tabular}{|c|c|c|c|c|c|c|c|c|c|}
\hline $\begin{array}{l}\text { Stab. } \\
\text { Method }\end{array}$ & $\begin{array}{c}\text { Tank } \\
\text { No. }\end{array}$ & $\begin{array}{l}\text { Supernate } \\
\text { volume } \\
\text { (gal) }\end{array}$ & $\begin{array}{c}\text { Saltcake } \\
\text { Volume } \\
\text { (gal) }\end{array}$ & $\begin{array}{l}\text { Sludge } \\
\text { volume } \\
\text { (gal) }\end{array}$ & $\begin{array}{c}\text { ILL }^{2} \\
\text { (in.) }\end{array}$ & $\begin{array}{c}\text { Porosity } \\
\text { (saltcake) }\end{array}$ & $\begin{array}{l}\text { Porosity } \\
\text { (sludge) }\end{array}$ & $\begin{array}{l}\text { PLR } \\
\text { (gal) }\end{array}$ & $\begin{array}{l}\text { DIL } \\
\text { (gal) }\end{array}$ \\
\hline $\mathrm{SN}$ & $A-102$ & 4,000 & 22,000 & 15,000 & - & 0.25 & 0.15 & 4,000 & 8,000 \\
\hline AR & A-103 & 5,000 & 0 & 366,000 & 138.9 & N/A & 0.15 & 43,000 & 45,000 \\
\hline AR & A-104 & 0 & 0 & 28,000 & - & N/A & 0.15 & 0 & 4,000 \\
\hline AR & $A-105^{3}$ & 0 & 0 & 51,000 & - & N/A & - & 0 & 0 \\
\hline AR & A-106 & 0 & 0 & 125,000 & - & $\mathrm{N} / \mathrm{A}$ & 0.15 & 1,000 & 9,000 \\
\hline SN & $A X-102$ & 0 & 23,000 & 7,000 & - & 0.25 & 0.15 & 0 & 7,000 \\
\hline AR & $A X-103$ & 0 & 104,000 & 8,000 & - & 0.25 & 0.15 & 11,000 & 23,000 \\
\hline AR & $A X-104$ & 0 & 0 & 8,000 & - & N/A & 0.15 & 0 & 1,000 \\
\hline SN & B-101 & 0 & 113,000 & 0 & - & 0.25 & $\mathrm{~N} / \mathrm{A}$ & 17,000 & 24,000 \\
\hline SN & B-102 & 4,000 & 28,000 & 0 & - & 0.25 & $\mathrm{~N} / \mathrm{A}$ & 4,000 & 7,000 \\
\hline SN & B-103 & 0 & 59,000 & 0 & - & 0.25 & N/A & 3,000 & 11,000 \\
\hline $\mathrm{SN}$ & B-104 & 1,000 & 61,000 & 309,000 & 132.0 & 0.25 & 0.15 & 42,000 & 45,000 \\
\hline$A R$ & B-105 & 0 & 130,000 & 28,000 & 46.8 & 0.25 & 0.15 & 16,000 & 20,000 \\
\hline $\mathrm{SN}$ & B-106 & 1,000 & 116,000 & 0 & - & 0.25 & $\mathrm{~N} / \mathrm{A}$ & 19,000 & 25,000 \\
\hline SN & B-107 & 1,000 & 71,000 & 93,000 & - & 0.25 & 0.15 & 19,000 & 22,000 \\
\hline SN & B-108 & 0 & 41,000 & 53,000 & - & 0.25 & 0.15 & 11,000 & 15,000 \\
\hline SN & B-109 & 0 & 64,000 & 63,000 & - & 0.25 & 0.15 & 17,000 & 21,000 \\
\hline AR & B-110 & 1,000 & 0 & 245,000 & 95.8 & $\mathrm{~N} / \mathrm{A}$ & 0.15 & 23,000 & 27,000 \\
\hline SN & B-111 & 1,000 & 0 & 236,000 & 87.3 & N/A & 0.15 & 20,000 & 23,000 \\
\hline SN & B-112 & 3,000 & 0 & 30,000 & - & N/A & 0.15 & 3,000 & 4,000 \\
\hline AR & B-201 & 1,000 & 0 & 28,000 & - & N/A & 0.15 & 1,000 & 4,000 \\
\hline $\mathrm{AR}$ & B-202 & 0 & 0 & 27,000 & - & N/A & 0.15 & 0 & 4,000 \\
\hline $\mathrm{AR}$ & B-203 & 1.000 & 0 & 50,000 & - & N/A & 0.15 & 1,000 & 5,000 \\
\hline $\mathrm{AR}$ & B-204 & 1,000 & 0 & 49,000 & - & N/A & 0.15 & 1,000 & 5,000 \\
\hline$A R$ & $B X-101$ & 1,000 & 0 & 42,000 & - & N/A & 0.15 & 1,000 & 4,000 \\
\hline AR & $\mathrm{BX}-102^{3}$ & 0 & 0 & 96,000 & - & N/A & - & 0 & 0 \\
\hline AR & $B X-103$ & 9,000 & 0 & 62,000 & - & N/A & 0.15 & 9,000 & 4,000 \\
\hline SN & $B X-104$ & 3,000 & 0 & 90,000 & - & $\mathrm{N} / \mathrm{A}$ & 0.15 & 3,000 & 4,000 \\
\hline SN & $\mathrm{BX}-105$ & 5,000 & 0 & 46,000 & - & N/A & 0.15 & 5,000 & 4,000 \\
\hline SN & $\mathrm{BX}-106$ & 0 & 0 & 38,000 & - & N/A & 0.15 & 0 & 4,000 \\
\hline JET & $B X-107$ & 1,000 & 0 & 344,000 & - & N/A & 0.13 & 33,000 & 36,000 \\
\hline SN & $B X-108$ & 0 & 0 & 26,000 & - & N/A & 0.15 & 0 & 4,000 \\
\hline JET & $B X-109$ & 0 & 0 & 193,000 & - & N/A & 0.20 & 20,000 & 25,000 \\
\hline SN & $B X-110$ & 3,000 & 71,000 & 133,000 & - & 0.25 & 0.15 & 26,000 & 28,000 \\
\hline JET & $B X-111$ & 1,000 & 136,000 & 25,000 & $21.3^{2}$ & 0.12 & 0.15 & 2,000 & 5,000 \\
\hline JET & $\mathrm{BX}-112$ & 1,000 & 0 & 164,000 & - & N/A & 0.09 & 7,000 & 9,000 \\
\hline JET & BY-101 & 0 & 278,000 & 109,000 & 89.4 & 0.10 & 0.15 & 24,000 & 28,000 \\
\hline JET & $B Y-102$ & 0 & 277,000 & 0 & 63.4 & 0.26 & N/A & 33,000 & 40,000 \\
\hline JET & $B Y-103$ & 0 & 391,000 & 9,000 & 116.1 & 0.20 & 0.15 & 53,000 & 58,000 \\
\hline JET & B.Y-104 & 0 & 176,000 & 150,000 & 87.7 & 0.25 & 0.15 & 36,000 & 40,000 \\
\hline JET & BY-107 & 0 & 226,000 & 40,000 & 70.2 & 0.25 & 0.15 & 35,000 & 39,000 \\
\hline JET & BY-108 & 0 & 74,000 & 154,000 & $57.1^{2}$ & 0.24 & 0.24 & 26,000 & 33,000 \\
\hline JET & BY-109 & 0 & 233,000 & 57,000 & $52.4^{2}$ & 0.33 & 0.15 & 26,000 & 31,000 \\
\hline JET & BY-110 & 0 & 295,000 & 103,000 & $60.0^{2}$ & 0.13 & 0.15 & 17,000 & 21,000 \\
\hline JET & BY-111 & 0 & 459,000 & 0 & $27.4^{2}$ & 0.25 & N/A & 6,000 & 14,000 \\
\hline JET & $B Y-112$ & 0 & 291,000 & 0 & 28.2 & 0.42 & N/A & 12,000 & 24,000 \\
\hline$A R$ & C-101 & 0 & 0 & 88.000 & - & N/A & 0.15 & 0 & 4,000 \\
\hline JET & C-102 & 0 & 0 & 316,000 & $94.3^{2}$ & N/A & 0.26 & 55,000 & 62,000 \\
\hline
\end{tabular}


Table 5-1. Estimated Drainable Interstitial Liquid and Pumpable Liquid Remaining Volumes for 119 Single-Shell Tanks ( 3 pages)

\begin{tabular}{|c|c|c|c|c|c|c|c|c|c|}
\hline $\begin{array}{l}\text { Stab. } \\
\text { Method }\end{array}$ & $\begin{array}{c}\text { Tank } \\
\text { No. }\end{array}$ & $\begin{array}{c}\text { Supernate } \\
\text { volume } \\
\text { (gal) }\end{array}$ & $\begin{array}{c}\begin{array}{c}\text { Saltcake } \\
\text { Volume } \\
\text { (gal) }\end{array} \\
\end{array}$ & $\begin{array}{c}\begin{array}{c}\text { Sludge } \\
\text { volume } \\
\text { (gal) }\end{array} \\
\end{array}$ & $\begin{array}{l}\mathrm{ILL}^{2} \\
\text { (in.) }\end{array}$ & $\begin{array}{l}\text { Porosity } \\
\text { (saltcake) }\end{array}$ & $\begin{array}{l}\text { Porosity } \\
\text { (sludge) }\end{array}$ & $\begin{array}{l}\text { PLR } \\
\text { (gal) }\end{array}$ & $\begin{array}{l}\text { DIL } \\
\text { (gal) }\end{array}$ \\
\hline SN & C-104 & 0 & 0 & 295,000 & - & $N / A$ & 0.15 & 30,000 & 34,000 \\
\hline AR & C.105 & 2,000 & 0 & 132,000 & - & N/A & 0.15 & 8,000 & 10,000 \\
\hline JET & C-107 & 0 & 0 & 257,000 & $67.7^{2}$ & N/A & 0.18 & 25,000 & 30,000 \\
\hline$\overline{A R}$ & C-108 & 0 & 0 & 66,000 & - & N/A & 0.15 & 0 & 4,000 \\
\hline AR & C-109 & 4,000 & 0 & 62,000 & - & N/A & 0.15 & 4,000 & 4,000 \\
\hline JET & C-110 & 1,000 & 0 & 177,000 & $56.7^{2}$ & $N / A$ & 0.27 & 30,000 & 37,000 \\
\hline $\mathrm{SN}$ & C-111 & 0 & 0 & 57,000 & - & $\mathrm{N} / \mathrm{A}$ & 0.15 & 0 & 4,000 \\
\hline$\overline{A R}$ & $\mathrm{C}-112$ & 0 & 0 & 104,000 & - & N/A & 0.15 & 1,000 & 6,000 \\
\hline AR & $\mathrm{C}-201$ & 0 & 0 & 2,000 & - & N/A & 0.15 & 0 & 0 \\
\hline AR & C-202 & 0 & 0 & 1,000 & - & $\mathrm{N} / \mathrm{A}$ & 0.15 & 0 & 0 \\
\hline AR & C-203 & 0 & 0 & 5,000 & - & N/A & 0.15 & 0 & 1,000 \\
\hline$A R$ & C-204 & 0 & 0 & 3,000 & - & $\mathrm{N} / \mathrm{A}$ & 0.15 & 0 & 0 \\
\hline AR & S-104 & 1,000 & 0 & 293,000 & 111.2 & N/A & 0.15 & 31,000 & 34,000 \\
\hline JET & S-105 & 0 & 454,000 & 2,000 & 53.8 & 0.33 & 0.15 & 33,000 & 42,000 \\
\hline JET & $S-108$ & 0 & 445,000 & 5,000 & $16.7^{2}$ & 0.17 & 0.15 & 0 & 4,000 \\
\hline JET & S-110 & 0 & 259,000 & 131,000 & $92.1^{2}$ & 0.13 & 0.13 & 27,000 & 30,000 \\
\hline AR & SX-107 & 0 & 0 & 104,000 & - & N/A & 0.15 & 0 & 6,000 \\
\hline AR & $S X-108^{3}$ & 0 & 0 & 87,000 & $\cdot$ & N/A & - & 0 & 0 \\
\hline AR & $5 x-109^{3}$ & 0 & 175,000 & 75,000 & - & - & - & 0 & 0 \\
\hline AR & $S X-110^{3}$ & 0 & 0 & 62,000 & - & N/A & - & 0 & 0 \\
\hline SN & $S X-111$ & 0 & 0 & 122,000 & - & N/A & 0.15 & 3,000 & 8,000 \\
\hline AR & $S X-112$ & 0 & 0 & 108,000 & - & $N / A$ & 0.15 & 1,000 & 6,000 \\
\hline AR & $S X-113^{3}$ & 0 & 0 & 31,000 & - & N/A & - & 0 & 0 \\
\hline AR & SX-114 & 0 & 34,000 & 147,000 & - & 0.25 & 0.15 & 15,000 & 21,000 \\
\hline AR & $S X-115^{3}$ & 0 & 0 & 12,000 & + & N/A & - & 0 & 0 \\
\hline $\mathrm{SN}$ & $T-101$ & 1,000 & 64,000 & 37,000 & - & 0.25 & 0.15 & 16,000 & 20,000 \\
\hline$\overline{A R}$ & $T-102$ & 13,000 & 0 & 19,000 & - & $\mathrm{N} / \mathrm{A}$ & 0.15 & 11,000 & 3,000 \\
\hline AR & $T \cdot 103$ & 4,000 & 0 & 23,000 & - & N/A & 0.15 & 3,000 & 3,000 \\
\hline$A R$ & $T-105$ & 0 & 0 & 98,000 & - & N/A & 0.15 & 0 & 5,000 \\
\hline AR & $T-106^{3}$ & 2,000 & 0 & 19,000 & - & N/A & - & 2,000 & 0 \\
\hline JET & $T-107$ & 0 & 0 & 173,000 & $65.6^{2}$ & N/A & 0.21 & 20,000 & 34,000 \\
\hline$A R$ & $T-108$ & 0 & 23,000 & 21,000 & - & 0.25 & 0.15 & 0 & 5,000 \\
\hline $\mathrm{AR}$ & $\mathrm{T}-109$ & 0 & 58,000 & 0 & - & 0.25 & N/A & 3,000 & 10,000 \\
\hline JET & $T \cdot 111$ & 0 & 0 & 446,000 & $146.0^{2}$ & N/A & 0.10 & 35,000 & 38,000 \\
\hline AR & $T-112$ & 7,000 & 0 & 60,000 & - & $\mathrm{N} / \mathrm{A}$ & 0.15 & 7,000 & 4,000 \\
\hline AR & $T-201$ & 1,000 & 0 & 28,000 & - & N/A & 0.15 & 1,000 & 4,000 \\
\hline$\overline{A R}$ & $T-202$ & 0 & 0 & 21,000 & - & N/A & 0.15 & 0 & 3,000 \\
\hline$A R$ & T-203 & 0 & 0 & 35,000 & - & N/A & 0.15 & 0 & 5,000 \\
\hline AR & $T-204$ & 0 & 0 & 38,000 & - & N/A & 0.15 & 0 & 5,000 \\
\hline AR & $T X-101$ & 3,000 & 10,000 & 74,000 & - & 0.25 & 0.15 & 7,000 & 8,000 \\
\hline JET & $T X-102$ & 0 & 217,000 & 0 & $34.5^{2}$ & 0.36 & N/A & 16,000 & 27,000 \\
\hline JET & $\mathrm{TX}-103$ & 0 & 157,000 & 0 & 34.0 & 0.25 & N/A & 11,000 & 18,000 \\
\hline $\mathrm{SN}$ & TX-104 & 5,000 & 37,000 & 23,000 & - & 0.25 & 0.15 & 9,000 & 9,000 \\
\hline JET & $\mathrm{TX}-105$ & 0 & 609,000 & 0 & 31.3 & 0.38 & $\mathrm{~N} / \mathrm{A}$ & 14,000 & 25,000 \\
\hline JET & $T X-106^{4}$ & 0 & 341,000 & 0 & $64.0^{2}$ & 0.24 & N/A & 30,000 & 37,000 \\
\hline AR & TX-107 & 1,000 & 27,000 & 8,000 & - & 0.25 & 0.15 & 1,000 & 6,000 \\
\hline JET & TX-108 & 0 & 128,000 & 6,000 & $19.6^{2}$ & 0.25 & 0.15 & 1,000 & 8,000 \\
\hline JET & $\mathrm{TX}-109^{1}$ & 0 & 0 & 384,000 & 125.8 & N/A & 0.15 & 2,000 & 6,000 \\
\hline
\end{tabular}


RPP-5556, Rev. 0

Table 5-1. Estimated Drainable Interstitial Liquid and Pumpable Liquid Remaining Volumes for 119 Single-Shell Tanks (3 pages)

\begin{tabular}{|c|c|c|c|c|c|c|c|c|c|}
\hline $\begin{array}{c}\text { Stab. } \\
\text { Method }\end{array}$ & $\begin{array}{c}\text { Tank } \\
\text { No. }\end{array}$ & $\begin{array}{l}\text { Supernate } \\
\text { volume } \\
\text { (gal) }\end{array}$ & $\begin{array}{c}\text { Saltcake } \\
\text { Volume } \\
\text { (gal) }\end{array}$ & $\begin{array}{c}\begin{array}{c}\text { Sludge } \\
\text { volume } \\
\text { (gal) }\end{array}\end{array}$ & $\begin{array}{l}\text { ILL }^{2} \\
\text { (in.) }\end{array}$ & $\begin{array}{c}\text { Porosity } \\
\text { (saltcake) }\end{array}$ & $\begin{array}{r}\text { Porosity } \\
\text { (sludge) }\end{array}$ & $\begin{array}{l}\text { PLR } \\
\text { (gal) }\end{array}$ & $\begin{array}{l}\text { DIL } \\
\text { (gal) }\end{array}$ \\
\hline JET & $T X-110$ & 0 & 425,000 & 37,000 & $33.0^{2}$ & 0.26 & 0.15 & 10,000 & 14,000 \\
\hline JET & $T X-111$ & 0 & 327,000 & 43,000 & $30.0^{2}$ & 0.18 & 0.15 & 6,000 & 10,000 \\
\hline JET & $T X-112$ & 0 & 649,000 & 0 & $62.5^{2}$ & 0.17 & $\mathrm{~N} / \mathrm{A}$ & 21,000 & 26,000 \\
\hline JET & TX-113 & 0 & 424,000 & 183,000 & $46.9^{2}$ & 0.17 & 0.17 & $\$ 4,000$ & 18,000 \\
\hline JET & $T X-114$ & 0 & 531,000 & 4,000 & $36.7^{2}$ & 0.21 & 0.15 & 11,000 & 17,000 \\
\hline JET & $T X-115$ & 0 & 568,000 & 0 & $35.4^{2}$ & 0.32 & $\mathrm{~N} / \mathrm{A}$ & 15,000 & 25,000 \\
\hline JET & $T X-116$ & 0 & 563,000 & 68,000 & $52.0^{2}$ & 0.20 & 0.15 & 17,000 & 21,000 \\
\hline JET & $T X-117$ & 0 & 597,000 & 29,000 & $30.0^{2}$ & 0.16 & 0.15 & 5,000 & 10,000 \\
\hline JET & $T X-118$ & 0 & 266,000 & 34,000 & $39.7^{2}$ & 0.35 & 0.15 & 20,000 & 24,000 \\
\hline JET & TY-101 & 0 & 46,000 & 72,000 & $17.0^{2}$ & 0.08 & 0.08 & 0 & 2,000 \\
\hline $\mathrm{AR}$ & $T Y-102$ & 0 & 64,000 & 0 & - & 0.25 & $\mathrm{~N} / \mathrm{A}$ & 5,000 & 12,000 \\
\hline JET & $T Y-103$ & 0 & 0 & 162,000 & $56.0^{2}$ & $\mathrm{~N} / \mathrm{A}$ & 0.15 & 16,000 & 20,000 \\
\hline AR & $T Y-104$ & 0 & 0 & 43,000 & - & $\mathrm{N} / \mathrm{A}$ & 0.15 & 0 & 4,000 \\
\hline JET & $T Y-105$ & 0 & 0 & 231,000 & $70.0^{2}$ & N/A & 0.07 & 10,000 & 12,000 \\
\hline $\mathrm{AR}$ & TY-106 & 0 & 0 & 21,000 & $\cdot$ & $\mathrm{N} / \mathrm{A}$ & 0.15 & 0 & 3,000 \\
\hline $\mathrm{AR}$ & $U-101$ & 3,000 & 0 & 22,000 & - & N/A & 0.15 & 2,000 & 3,000 \\
\hline AR & $\mathrm{U}-104^{3}$ & 0 & 43,000 & 79,000 & - & - & - & 0 & 0 \\
\hline$\overline{A R}$ & $U-110$ & 0 & 0 & 186,000 & - & N/A & 0.15 & 14,000 & 18,000 \\
\hline AR & U-112 & 4,000 & 0 & 45,000 & - & $\mathrm{N} / \mathrm{A}$ & 0.15 & 4,000 & 4,000 \\
\hline$A R$ & U-201 & 1,000 & 0 & 4,000 & - & $\mathrm{N} / \mathrm{A}$ & 0.15 & 1,000 & 1,000 \\
\hline $\mathrm{SN}$ & $\mathrm{U}-202$ & 1,000 & 0 & 4,000 & - & $\mathrm{N} / \mathrm{A}$ & 0.15 & 1,000 & 1,000 \\
\hline AR & U-203 & 1,000 & 0 & 2,000 & - & $\mathrm{N} / \mathrm{A}$ & 0.15 & 1,000 & 0 \\
\hline SN & U-204 & 1,000 & 0 & 2,000 & $\cdot$ & $\mathrm{N} / \mathrm{A}$ & 0.15 & 1,000 & 0 \\
\hline TOTAL & & 104,000 & $11,280,000$ & $9,228,000$ & & & & $1,259,000$ & $1,695,000$ \\
\hline
\end{tabular}

$\mathrm{N} / \mathrm{A}=$ not applicable: designation given to porosity values if there was " 0 " saltcake or sludge, respectively.

${ }^{1}$ Capillary height was measured for this tank (Boettger 1997)

${ }^{2}$ Where footnoted, the ILL measurement was a diptube measurement, all other ILLs are LOW measurements.

${ }^{3}$ Tank Leak Failure, DIL, and PLR calculated to be " 0 " by setting drainable porosity values to " 0 ". 
RPP-5556, Rev. 0

\subsection{REFERENCES}

Boettger, J. S., 1997, Single-Shell Tank Leak Stabilization Record, HNF-SD-RE-TI-178, Rev. 6, Lockheed Martin Hanford Company, Richland, Washington.

Field, J. G., and D. T. Vladimiroff, 1999, Updated Pumpable Liquid Volume Estimates and Jet Pump Durations for Interim Stabilization of Remaining Single-Shell Tanks, HNF-2978, Rev. 1, Lockheed Martin Hanford Corp., Richland, Washington.

Hanlon, B. M., 1999, Waste Tank Summary Report for Month ending August 31, 1999, HNF-EP-0182-137, Fluor Daniel Hanford, Inc., Richland, Washington.

Kirk, J. J., 1980, Permeability, Porosity, and Capillarity of Hanford Waste Material and Its Limits of Pumpability, RHO-CD-925, Rev. 2, Rockwell Hanford Operations, Richland, Washington.

Nelson, J. L., and P. C. Ohl, 1999, Single-Shell Tank Leak History Compilation, Volume I of II: Summary, HNF-4872, Vol. I, Rev. 0, Lockheed Martin Hanford Corp. for Fluor Daniel Hanford, Inc., Richland, Washington.

Saueressig, D. J., 1997, Subcontract Number 80232764-9-K001, Completion of Interim Stabilization of Single-Shell Tank 241-BY-103 (Completion of Hanford Federal Facility Agreement and Consent Order, Target M-41-27-T02), (Letter, LMHC-9761114 to A. M. Umek, November 25), Lockheed Martin Hanford Corp., Richland, Washington.

Thompson, R. R., 1999, Leak Assessment for Tanks 241-SX-102 and 241-SX-109, RPP-5515, Rev. 0, Lockheed Martin Hanford Corp., Richland, Washington.

Vladimiroff, D. T., V. C. Boyles, J. O. Honeyman, J. R. Kriskovich, K. Parnell, R. P. Raven, D. J. Saueressig, W. R. Swita, J. G. Lewis, C. R. Hutchins, B. D. Zimmerman, A. D. Basche, A. J. Diliberto, M. R. Koch, T. M. Horner, J. A. Crawford, M. N. Johnson, and J. A. Morrison, 1999, Single-Shell Tank Interim Stabilization Project Plan, HNF-2358, Rev. 3, Lockheed Martin Hanford Corp., Richland, Washington. 


\section{RPP-5556, Rev. 0}

This page intentionally left blank. 
RPP-5556, Rev. 0

APPENDIX A

POROSITY CALCULATIONS AND BASIS

FOR DRAINABLE INTERSTITIAL LIQUID ESTIMATES

DIFFERING FROM BOETTGER (1997) 
RPP-5556, Rev. 0

Most of the tank DIL calculations differ somewhat from those presented in TI-178 based on updated tank volume estimates, calculations based on new average porosity values, and/or different assumptions regarding the position and height of the capillary region. Volumes, porosities, and capillary height values used for calculations in this document for the 119 SSTs are shown in Table 5-1.

Only tanks designated "catastrophic leakers", those with negligible DIL, or tanks for which jet pump porosity values were recalculated and differ from the TI-178 document (Boettger 1997) are discussed further in this section.

\section{A1.0 Catastrophic Leakers}

241-A-105, 241-BX-102, 241-SX-108, 241-SX-110, 241-SX-113, 241-SX-115, 241-T-106, and 241-U-104 were designated Catastrophic Leakers (Nelson and Ohl 1999); DIL was assumed to be "0" (see Section 1.0).

\section{A2.0 Leakers with Negligible Drainable Interstitial Liquid Remaining}

SX-108 - Tank Leak, applying the same criteria used for tank 241-SX-109 (Thompson 1999), tank determined to have little or no remaining DIL.

SX-109 - Tank Leak, tank determined to have little or no remaining DIL (Thompson 1999)

\section{A3.0 Jet Pump Porosity Differences from Boettger (1997)}

BY-108 - An average value of $12.5 \%$ drainable porosity was assumed previously (Boettger 1997). However, sufficient information is available to calculate a tank specific drainable porosity of $24 \%$. The calculation is as follows:

The starting liquid level was $99.5 \mathrm{in}$. The liquid level dropped to $57.1 \mathrm{in.}$ in the diptube after pumping was completed, and the liquid level in the diptube came to equilibrium. This equates to a $116 \mathrm{kgal}$ drawdown. The estimated volume of liquid pumped was $27.3 \mathrm{kgal}$.

$$
\text { Drainable Porosity }=27.3 \mathrm{kgal} / 116 \mathrm{kgal}=24 \%
$$

Using the $24 \%$ drainable porosity value increases the estimated DIL from $8.8 \mathrm{kgal}$ (Boettger 1997) to $33.0 \mathrm{kgal}$. 
RPP-5556, Rev. 0

TX-106 - Used average drainable porosity values of $25 \%$ for saltcake and $15 \%$ for sludge (HNF-2978). The Boettger (1997) calculated drainable porosity of $2 \%$ is possible, but seems low because all other TX Farm drainable porosity calculations range from $16 \%$ to $38 \%$.

The capillary height was measured by lancing to be $58 \mathrm{in}$. for tank TX-106 (Boettger 1997). Although classified as saltcake, this waste had low permeability, as evidenced by the capillary height and length of time required for the liquid level to reach equilibrium after pumping). Therefore, capillary height was subtracted from the LOW for this tank.

The DIL value for TX-106 increased from $10.9 \mathrm{kgal}$ (Boettger 1997) to $37.0 \mathrm{kgal}$.

C-102 - The drainable porosity value shown in Boettger (1997) was used. The total waste volume below the ILL was 238,825 gal. Because the ILL is based on diptube measurements, capillary height is assumed to be above the ILL and should not be subtracted out. Also, the dish volume should be included in the DIL calculation and not subtracted out. The recalculated DIL volume is 62,000 gal, compared to the Boettger (1997) value of $30.2 \mathrm{kgal}$. The new DIL estimate exceeds the 50,000 gal stabilization criteria.

BY-103 - The drainable porosity and DIL calculation for this tank were not included in Boettger (1997). The tank was declared stabilized based on an estimated porosity of $13 \%$ and a DIL of $38.3 \mathrm{kgal}$ (Saueressig 1997). However, based on LOW measurements, and the assumptions presented in this document, the drainable porosity was re-calculated to be $19.5 \%$ with a DIL of $58 \mathrm{kgal}$. The LOW level at the start of pumping was $131.5 \mathrm{in}$. After pumping $17.4 \mathrm{kgal}$ (net production), the LOW dropped to $99.1 \mathrm{in}$. for about a year.

$$
\text { Porosity }=17,400 \mathrm{gal} /(131.5-99.1) \text { in. } * 2,754 \mathrm{gal} / \mathrm{in} .=19.5 \%
$$

Currently, the LOW level is 116.1 in. Intrusion is expected as the cause for the rising LOW level (Hanlon 1999). The current DIL calculation is:

$$
D I L=((116.1-12) \text { in. } * 2,754 \mathrm{gal} / \mathrm{in} .+12,500 \mathrm{gal}) * 0.195=58,000 \mathrm{gal} .
$$

Because the waste is classified as a saltcake, it was assumed that the 6-in. capillary height is above the saltcake. The slow backflow into the saltwell and neutron probe scans indicates that although the waste is classified as saltcake, it is highly impermeable and acts more like sludge. In this case, the capillary height would be subtracted from the ILL. The DIL falls below 50,000 gal if capillary height is subtracted from the ILL. 
RPP-5556, Rev. 0

This page intentionally left blank. 
RPP-5556, Rev. 0

APPENDIX B

SPREADSHEET CALCULATIONS AND VERIFICATION

B-1 


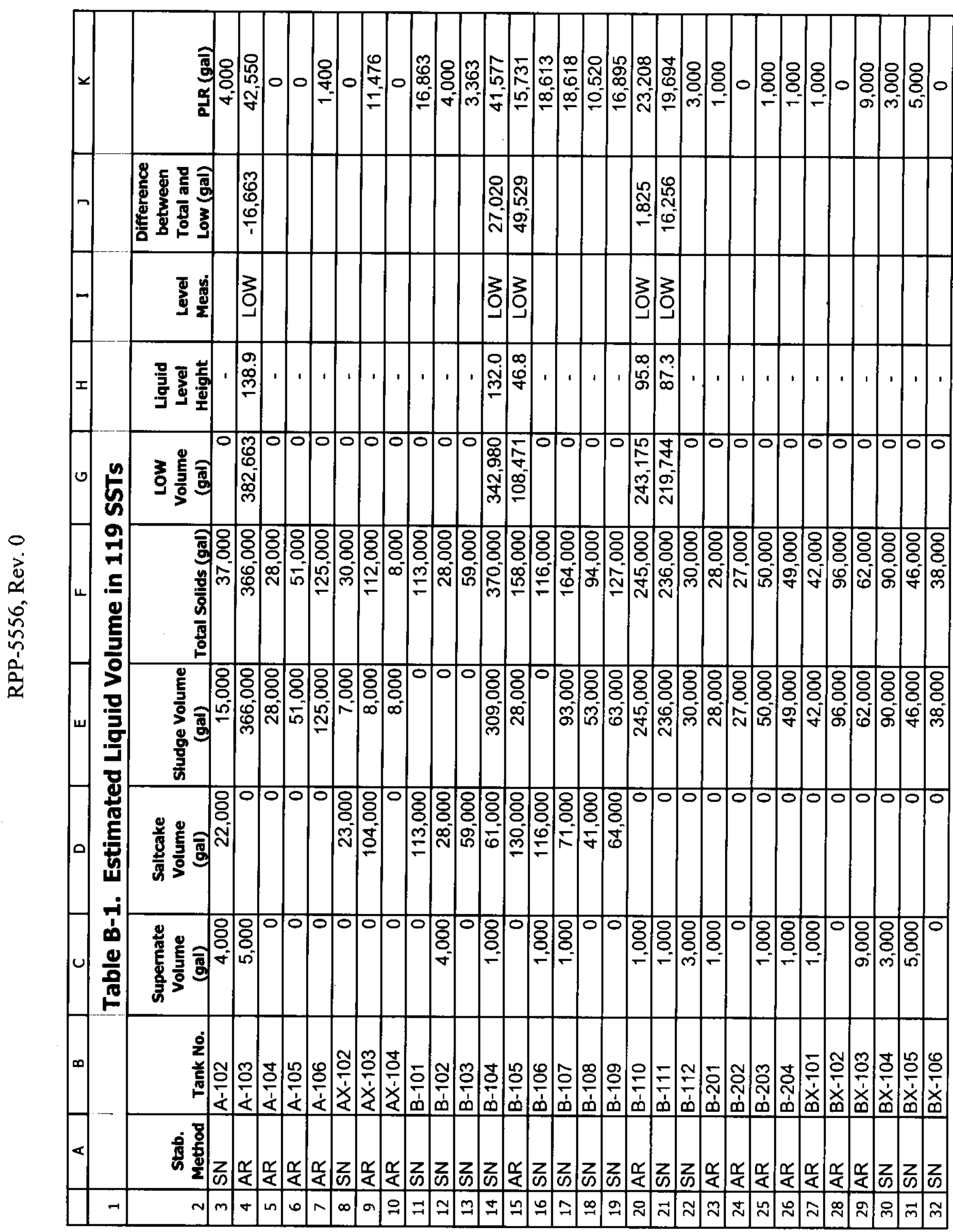




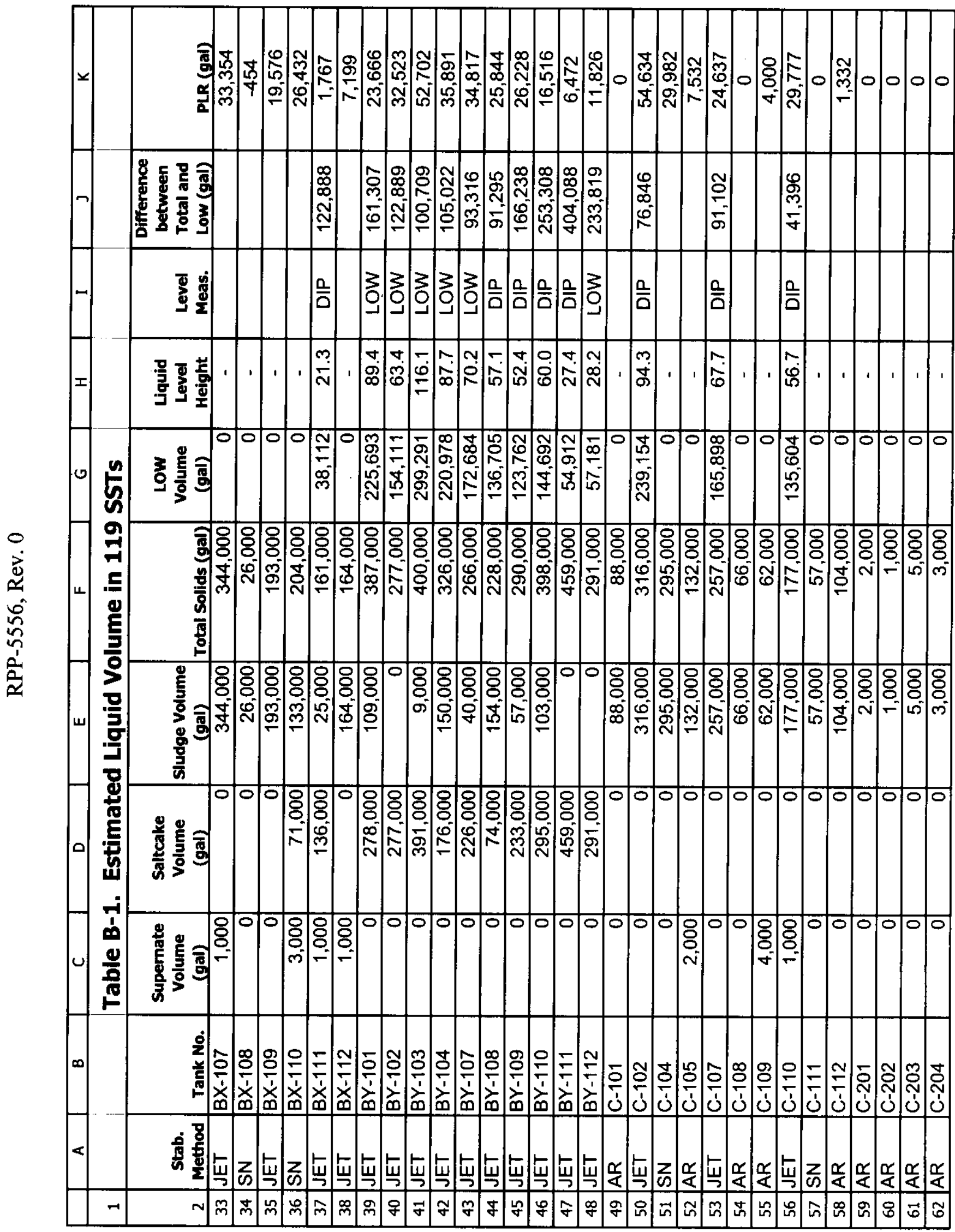




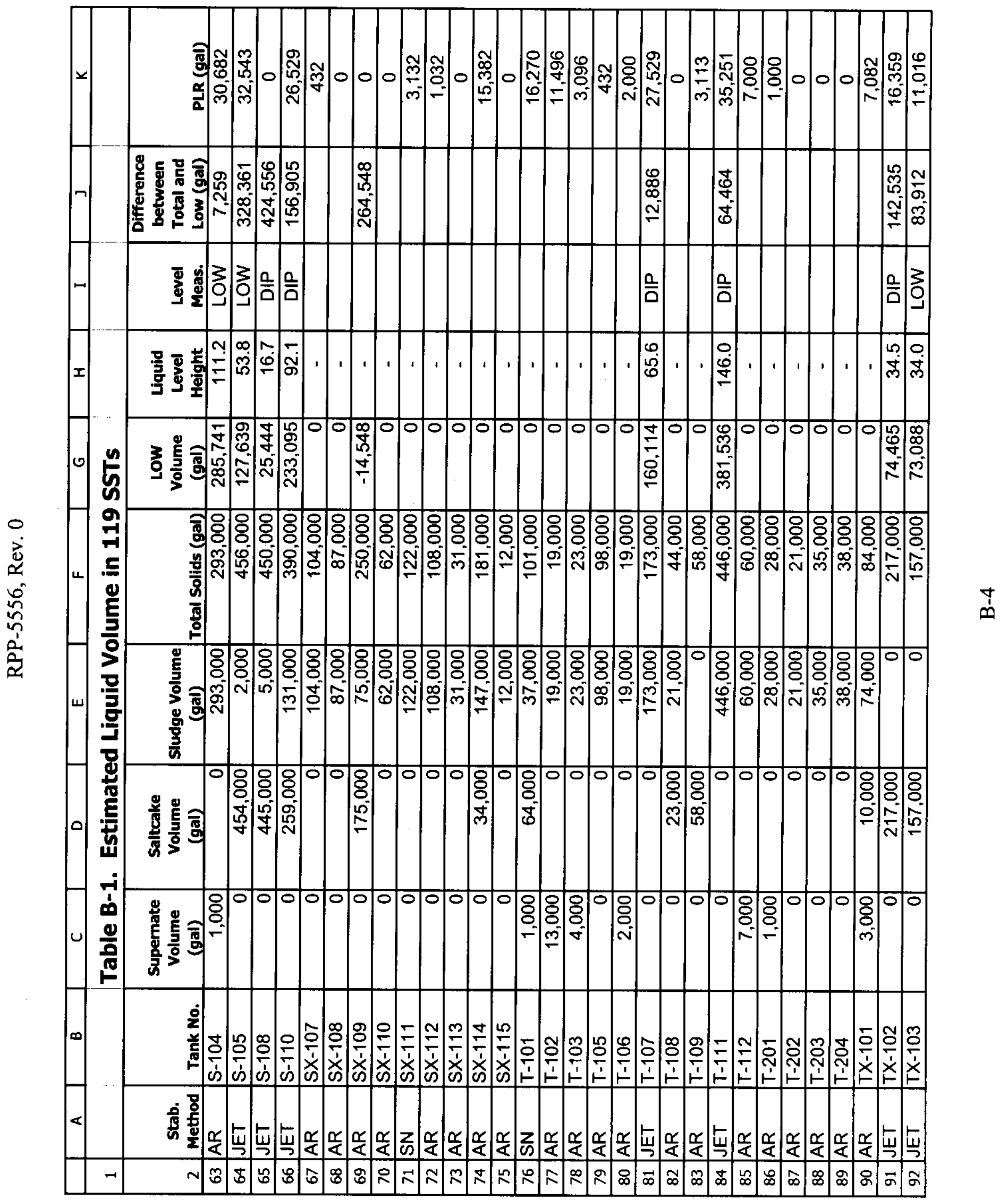




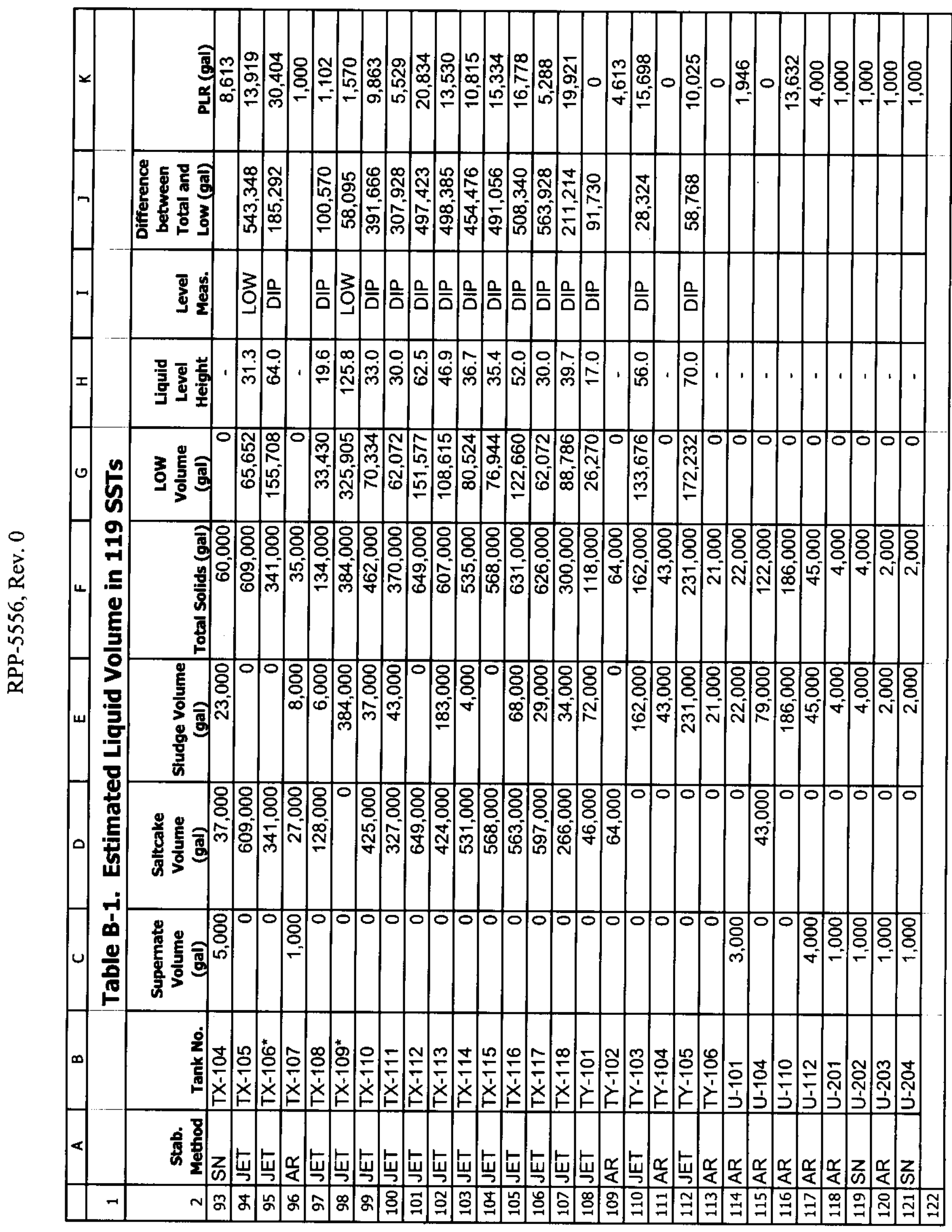




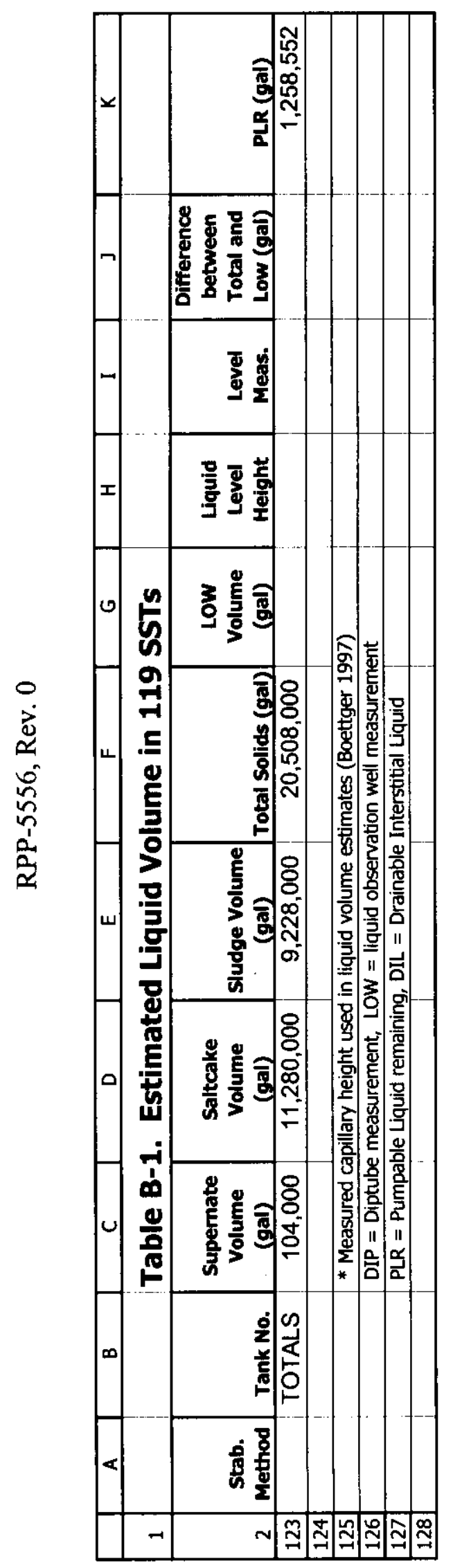

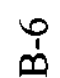




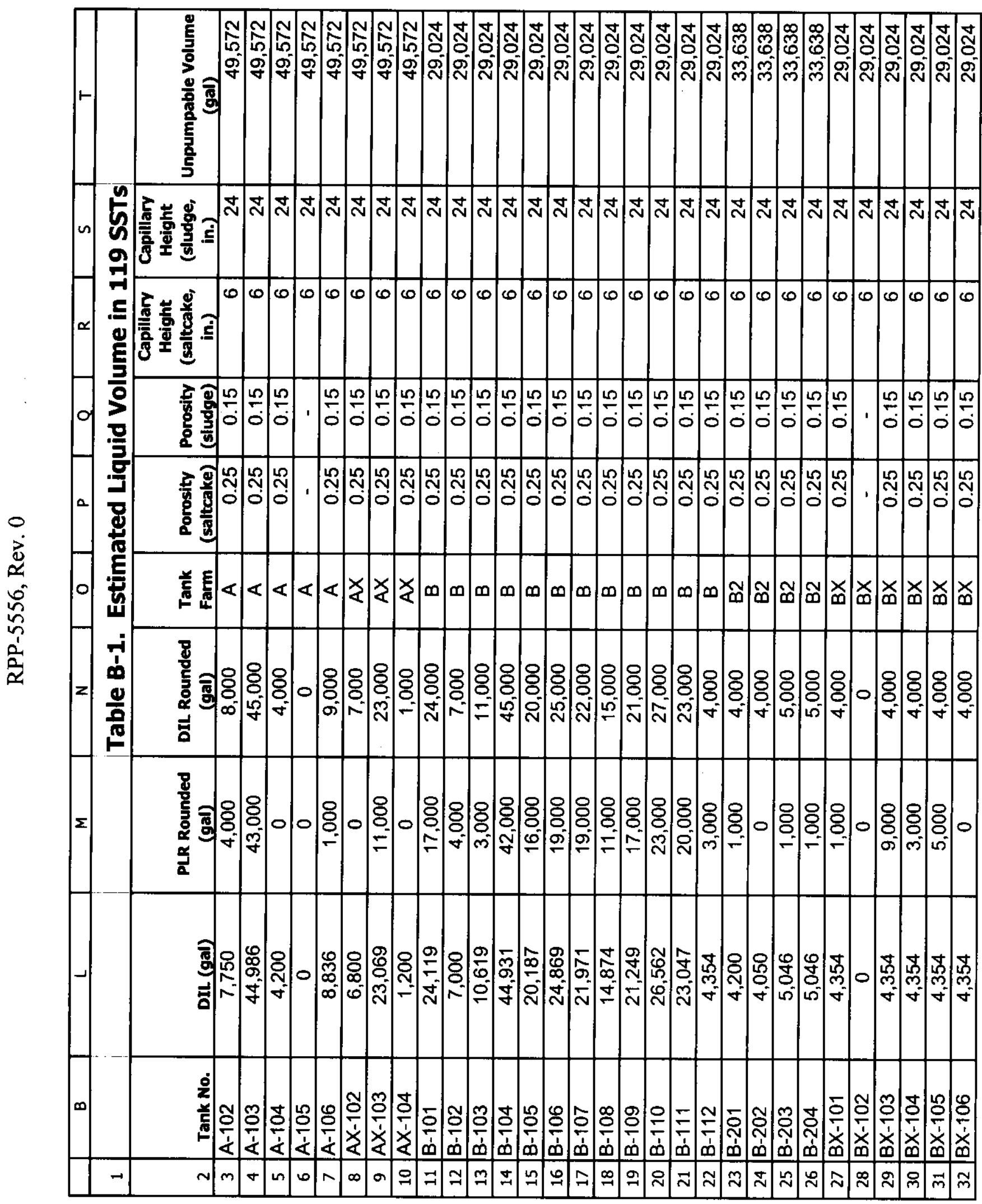




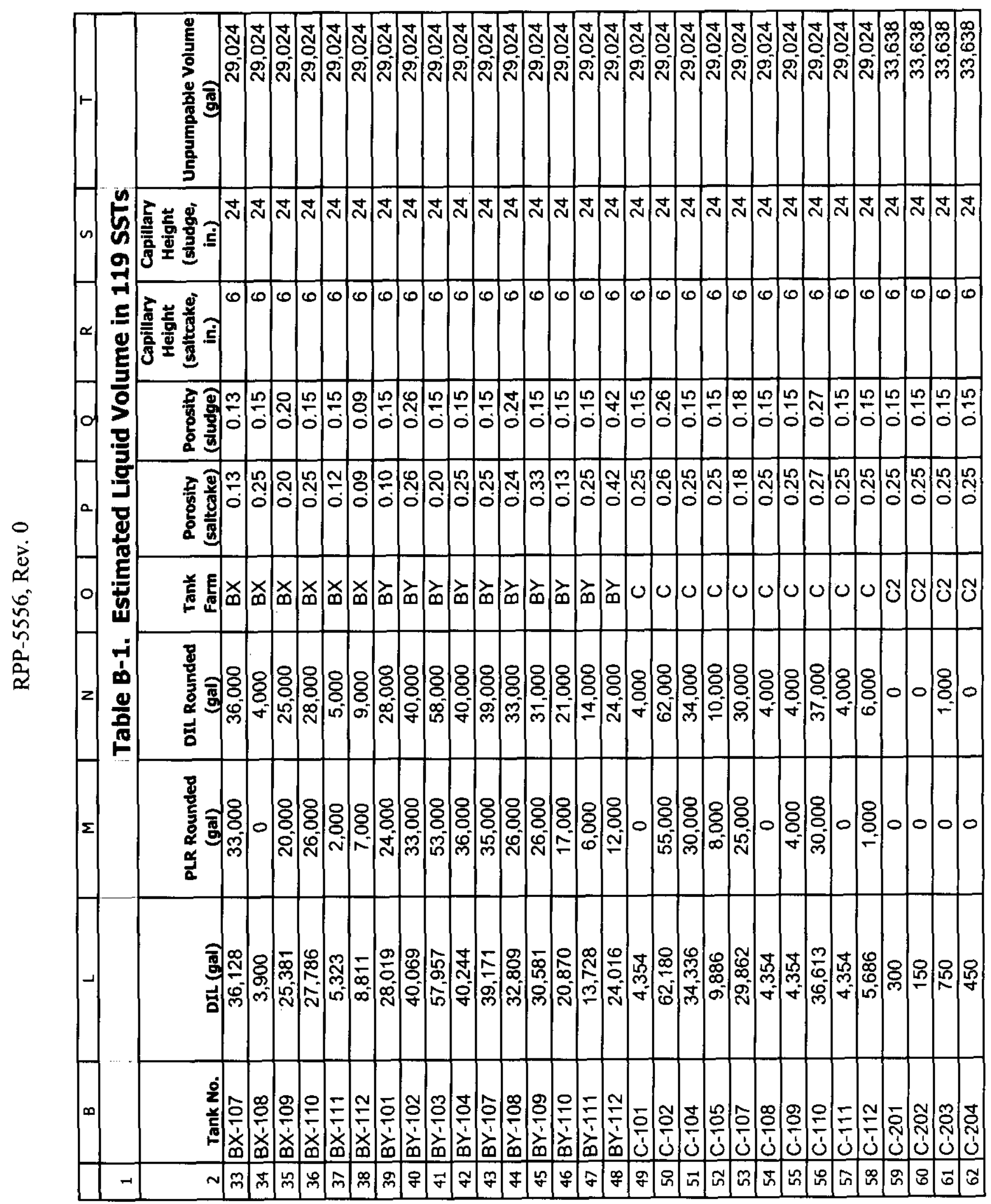




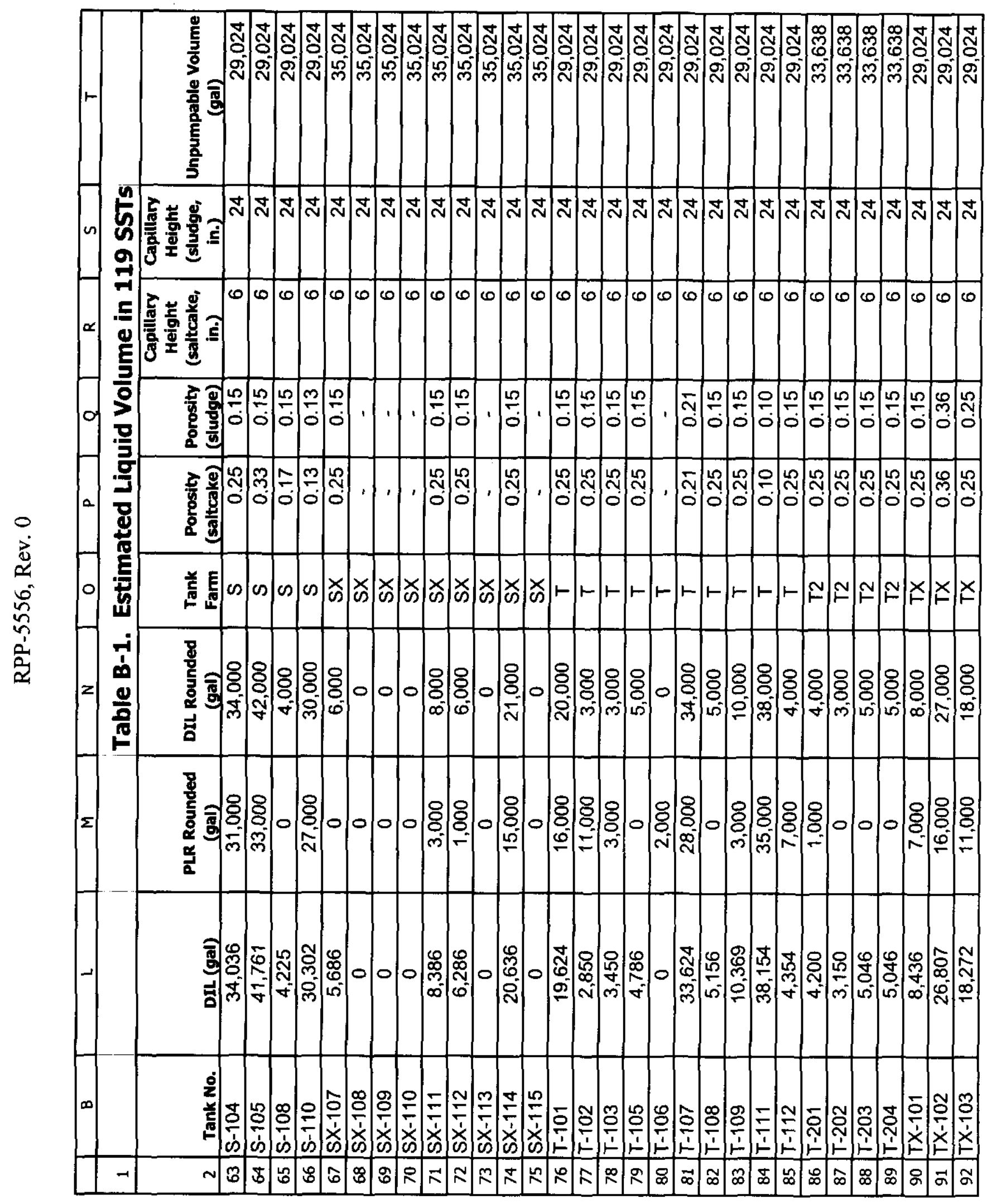




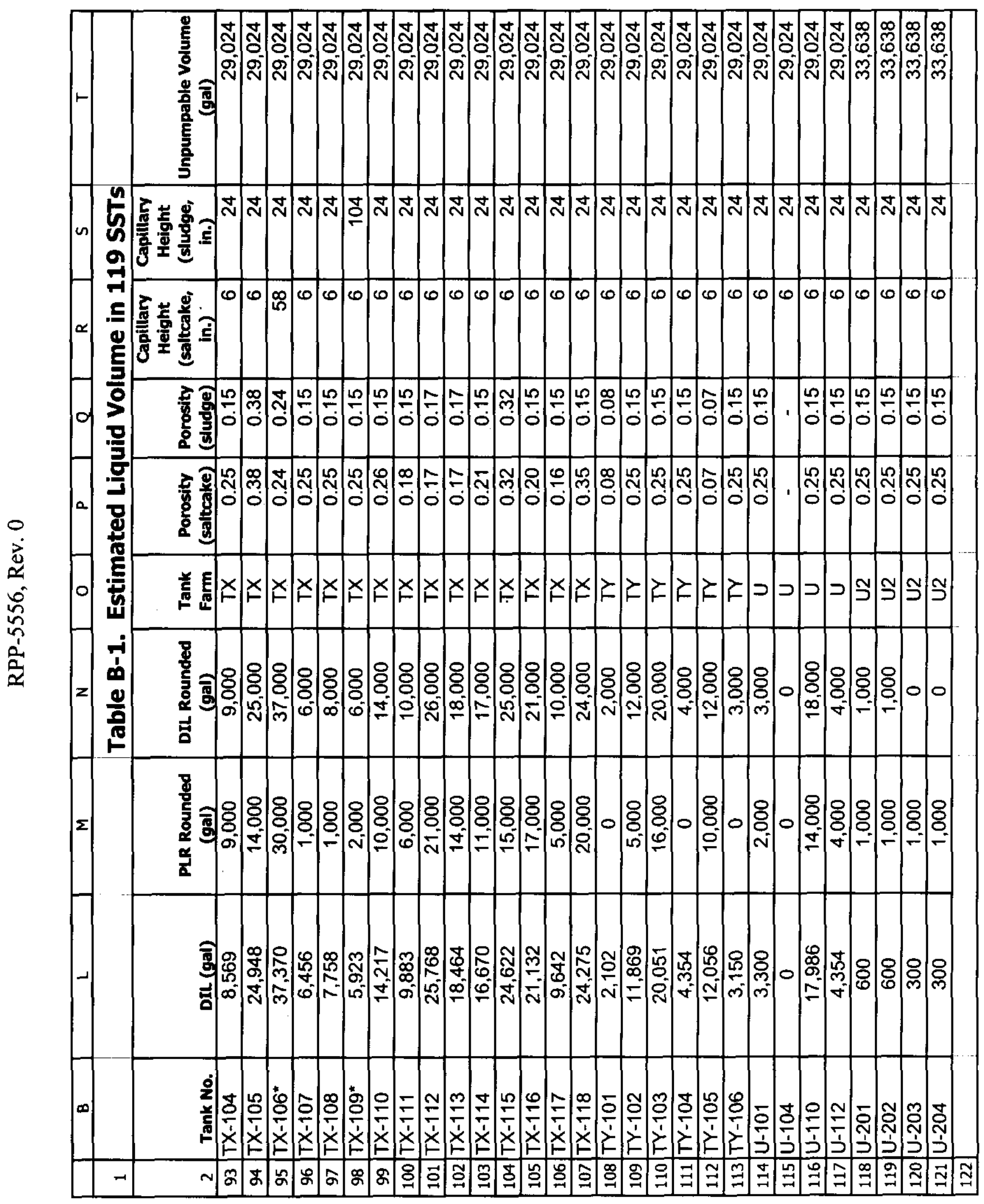




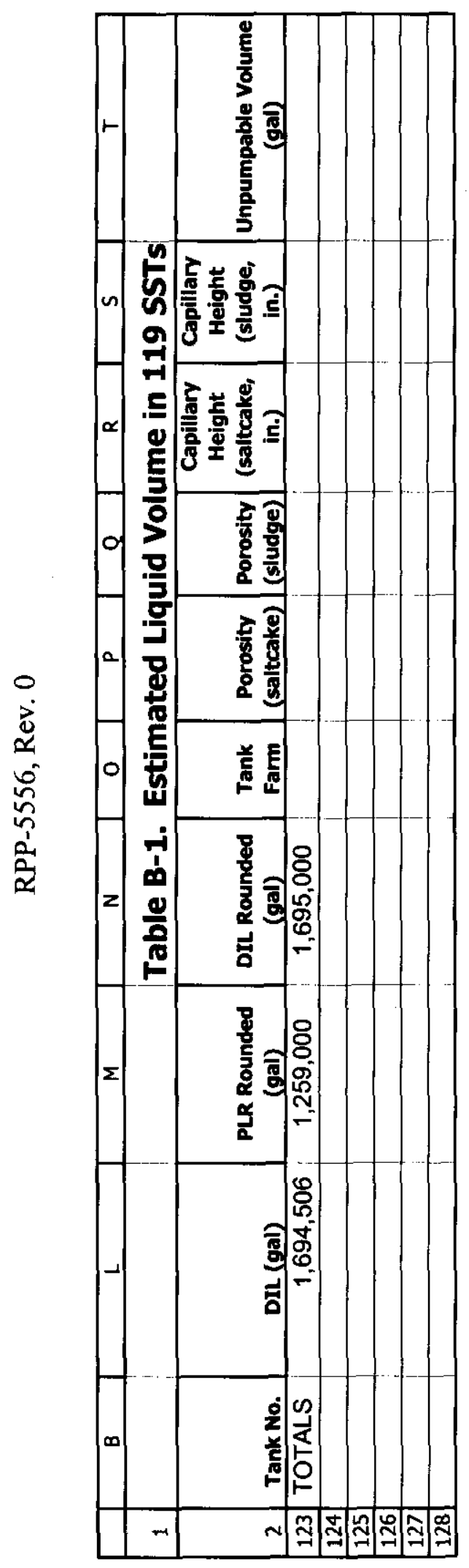

$\overline{\overline{\dot{m}}}$ 


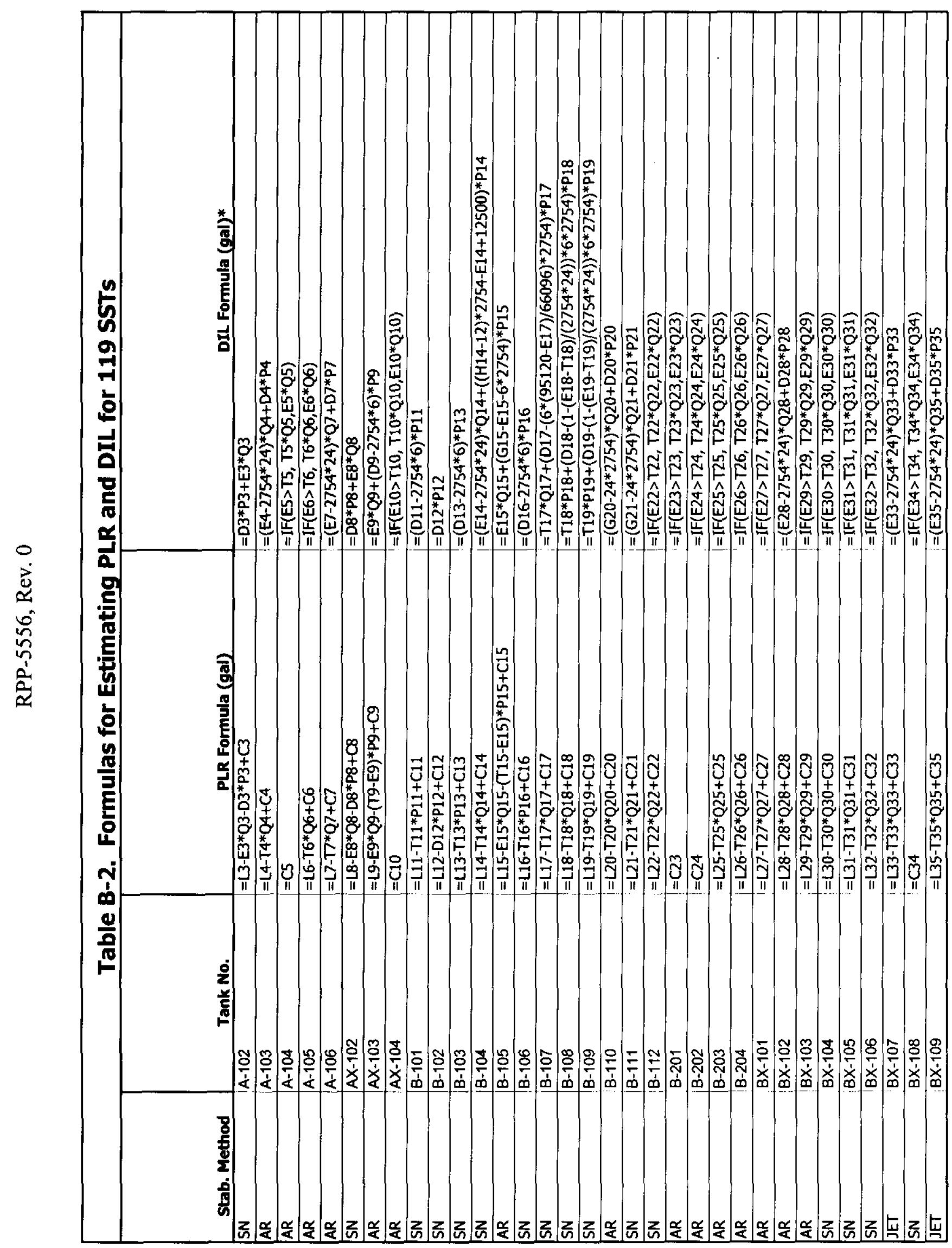

$\frac{1}{n}$ 


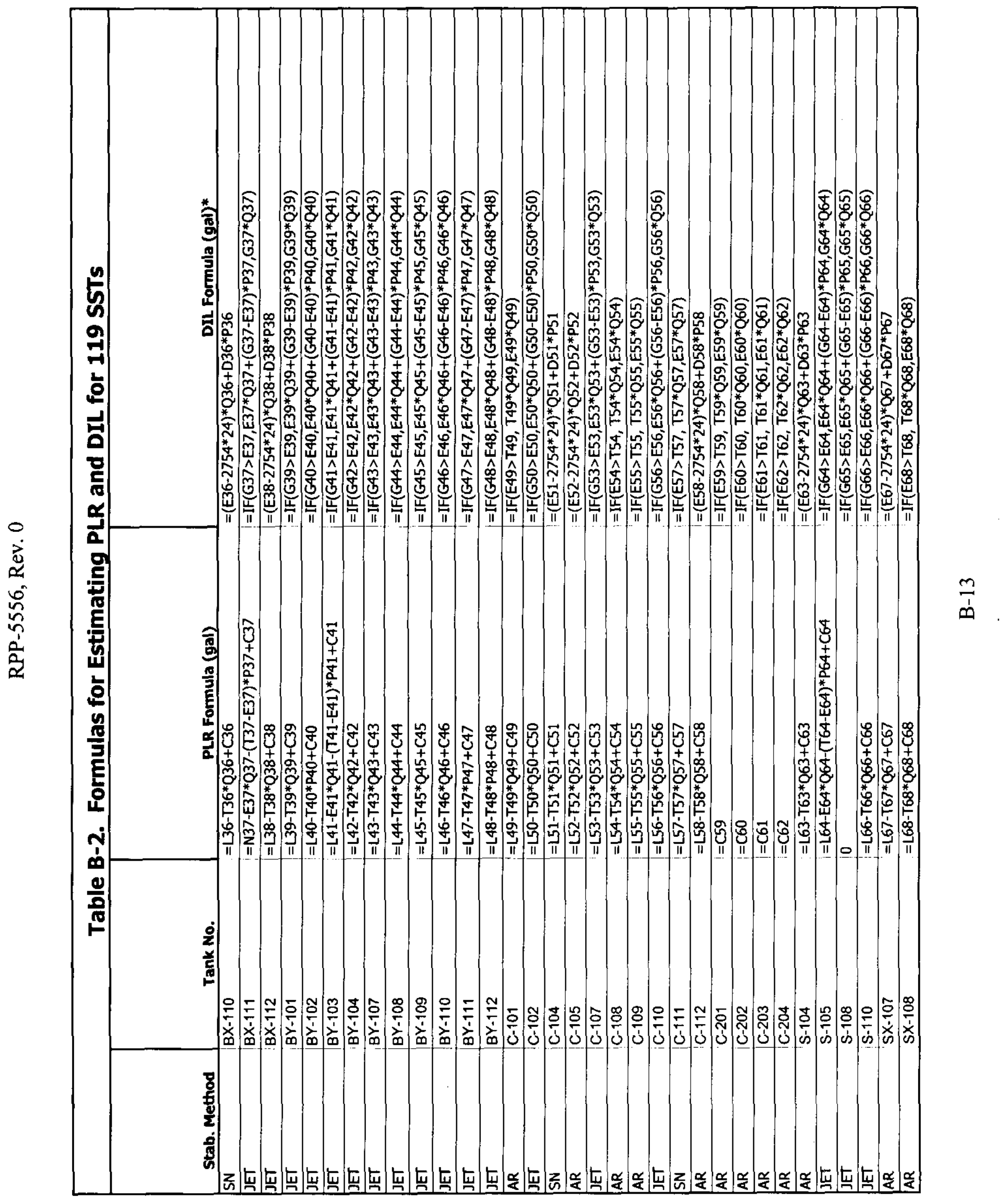




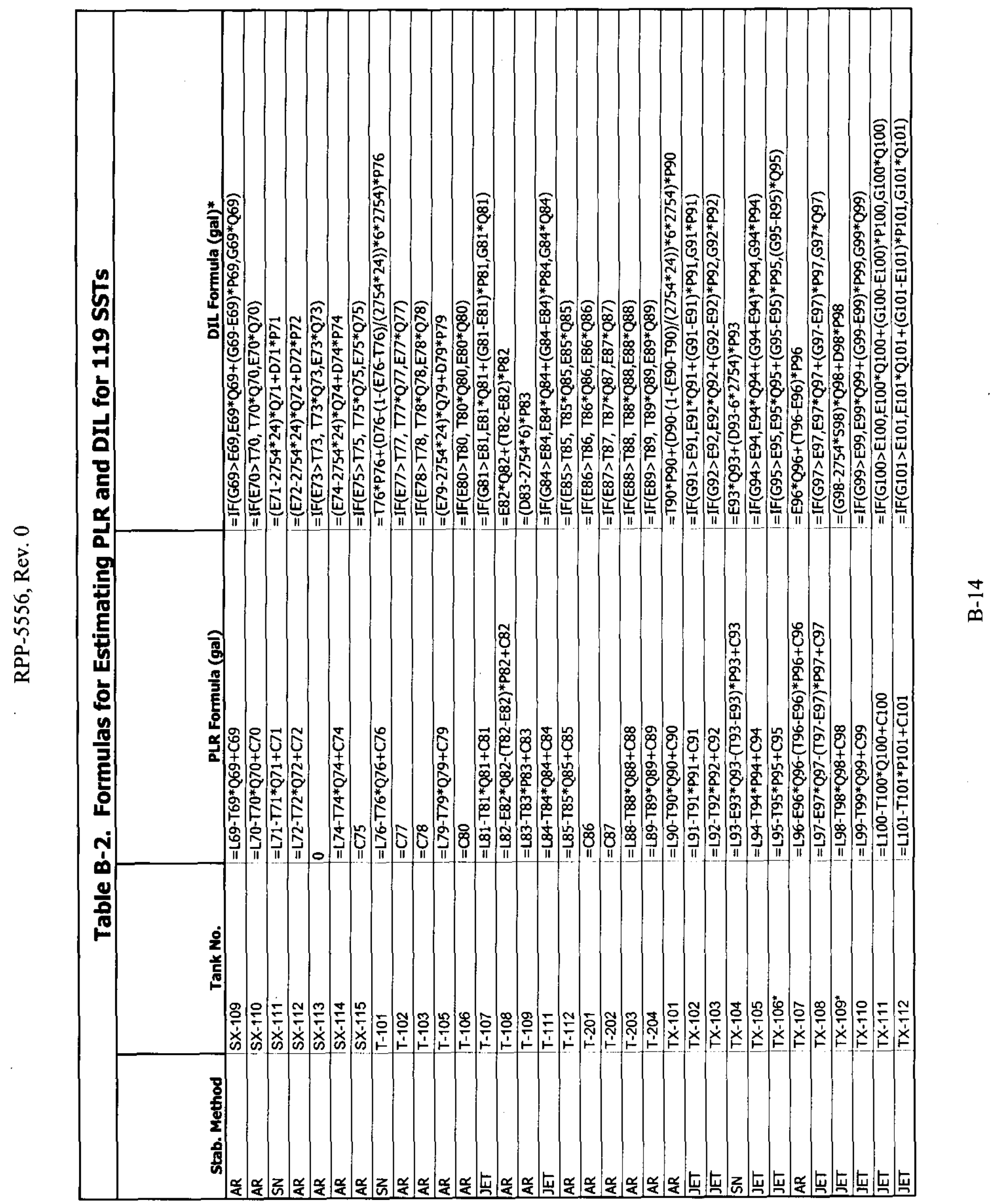




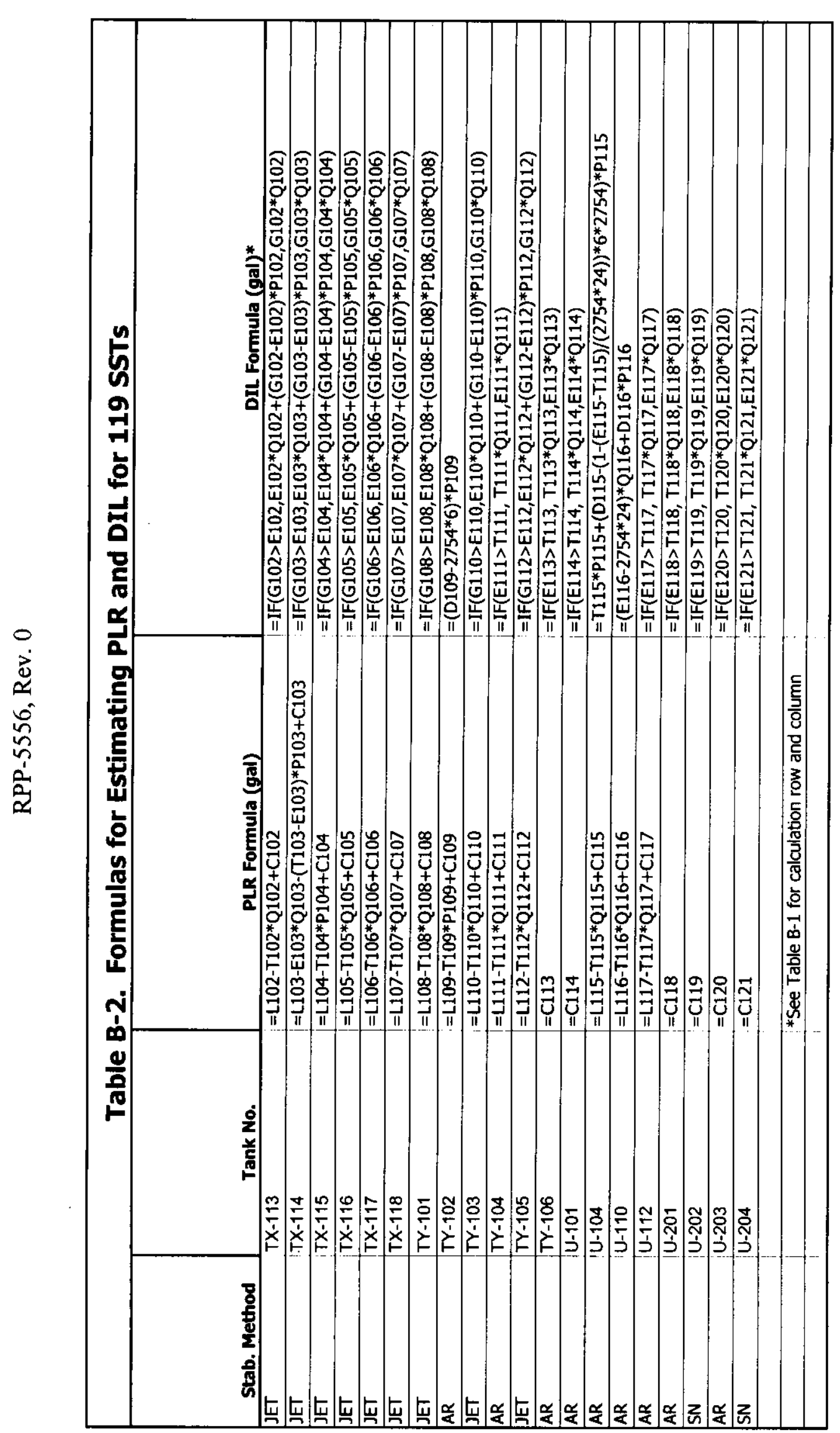

$\frac{n}{\dot{n}}$ 


\section{CHECKLIST FOR PEER REVIEW}

Document Reviewed: RPP-5556, Rev. 0

Scope of Review:

Yes No N/A

[ ] [] [x] Previous reviews complete and cover analysis, up to scope of this review, with no gaps.

[x] [ ] [ ] Problem completely, defined.

[ ] [] [x] Accident scenarios developed in a clear and logical manner.

[x] [] [ ] Necessary assumptions explicitly stated and supported.

[x] [ ] [ ] Computer codes and data files documented.

[x] [ ] [] Data used in calculations explicitly stated in document.

[x] [ ] [ ] Data checked for consistency with original source information as applicable.

[x] [] [] Mathematical derivations checked including dimensional consistency of results.

[x] [ ] [ ] Models appropriate and used within range of validity or use outside range of established validity justified.

[x] . [ ] [ ] Hand calculations checked for errors. Spreadsheet results should be treated exactly the same as hand calculations.

[x] [ ] [] Software input correct and consistent with document reviewed.

[x] [ ] [] Software output consistent with input and with results reported in document reviewed.

[x] [ ] [ ] Limits/criteria/guidelines applied to analysis results are appropriate and referenced.

[] [] [x] Safety margins consistent with good engineering practices. 


\section{RPP-5556, Rev. 0}

[] [] [x] Conclusions consistent with analytical results and applicable limits.

[x] [ ] [ ] Results and conclusions address all points required in the problem statement.

[ ] [ ] [x] Format consistent with appropriate NRC Regulatory Guide or other standards.

[x] [ ] [ ] Review calculation, comments, and/or notes are attached.

[x] [ ] [ ] Document approved

T. Albert Hu

1-20-2000

Reviewer 


\begin{tabular}{|c|c|c|c|c|c|}
\hline \multicolumn{6}{|c|}{ DISTRIBUTION SHEET } \\
\hline \multirow[b]{2}{*}{ Distribution } & \multirow{2}{*}{\multicolumn{3}{|c|}{ Process Control }} & \multicolumn{2}{|l|}{ Page 1 of 1} \\
\hline & & & & \multicolumn{2}{|c|}{ Date $\quad 02 / 03 / 00$} \\
\hline \multirow{2}{*}{\multicolumn{4}{|c|}{$\begin{array}{l}\text { Project Title/Work Order } \\
\text { RPP-5556, Rev. 0, "Updated Drainable Interstitial Liquid Volume } \\
\text { Estimates for } 119 \text { Single-She11 Tanks Declared Stabilized" }\end{array}$}} & \multirow{2}{*}{\multicolumn{2}{|c|}{$\begin{array}{ll}\text { EDT No. } & \text { EDT-628376 } \\
\text { ECN No. } & \text { N/A }\end{array}$}} \\
\hline & & & & & \\
\hline Name & MSIN & $\begin{array}{l}\text { Text } \\
\text { With } \\
\text { All } \\
\text { Attach. }\end{array}$ & Text Oniy & $\begin{array}{l}\text { Attach./ } \\
\text { Appendix } \\
\text { Only }\end{array}$ & $\begin{array}{l}\text { EDT/ECN } \\
\text { Only }\end{array}$ \\
\hline $\begin{array}{l}\text { CH2M Hill Hanford Group, Inc. } \\
\text { D. A. Barnes } \\
\text { V. C. Boyles } \\
\text { C. DeFigh-Price } \\
\text { J. N. Doeler } \\
\text { J. G. Field } \\
\text { B. M. Hanlon } \\
\text { T. L. Hissong } \\
\text { K. M. Hodgson } \\
\text { J. O. Honeyman } \\
\text { T. A. Hu } \\
\text { K. J. Hul1 } \\
\text { J. W. Hunt } \\
\text { N. W. Kirch } \\
\text { M. R. Koch } \\
\text { J. G. Kristofzski } \\
\text { R. E. Larson } \\
\text { P. C. Mi } 17 \text { er } \\
\text { R. E. Raymond } \\
\text { W. E. Ross } \\
\text { D. J. Saueressig } \\
\text { T.C.S.R.C. }\end{array}$ & $\begin{array}{l}\text { R2-12 } \\
\text { R2-11 } \\
\text { R2-12 } \\
\text { T4 }-07 \\
\text { R2-12 } \\
\text { T4-08 } \\
\text { S7-20 } \\
\text { R2-11 } \\
\text { H6-62 } \\
\text { R2-11 } \\
\text { T4-07 } \\
\text { R2-12 } \\
\text { R2-11 } \\
\text { S7-24 } \\
\text { H6-62 } \\
\text { T4-07 } \\
\text { R1-51 } \\
\text { S7-70 } \\
\text { R2-50 } \\
\text { S7 }-20 \\
\text { R1- } 10\end{array}$ & $\begin{array}{l}x \\
x \\
x \\
x \\
5 \\
x \\
x \\
x \\
x \\
x \\
x \\
x \\
x \\
x \\
x \\
x \\
x \\
x \\
x \\
x \\
x \\
x \\
x \\
x\end{array}$ & & & \\
\hline$\frac{\text { Flour Federal Services }}{\text { D. T. Vladimiroff }}$ & $S 7-20$ & $x$ & & & \\
\hline $\begin{array}{l}\text { Lockheed Martin Services, Inc. } \\
\text { Central Files }\end{array}$ & B1-07 & $x$ & & & \\
\hline$\frac{\text { MACTEC }}{\text { D. S. Rewinkle }}$ & $57-83$ & $x$ & & & \\
\hline $\begin{array}{l}\text { Office of River Protection } \\
\text { C. Pacheco } \\
\text { M. J. Royack } \\
\text { DOE Reading Room }\end{array}$ & $\begin{array}{l}H 6-60 \\
H 6-60 \\
H 2-53\end{array}$ & $\begin{array}{l}x \\
x \\
x\end{array}$ & & & \\
\hline
\end{tabular}

